\title{
Review \\ Cervid Prion Protein Polymorphisms: Role in Chronic Wasting Disease Pathogenesis
}

\author{
Maria Immaculata Arifin 1,2,3, Samia Hannaoui 1,2,3, Sheng Chun Chang 1,2,3, Simrika Thapa ${ }^{1,2,3}$, \\ Hermann M. Schatzl 1,2,3 (iD) and Sabine Gilch 1,2,3,*iD \\ 1 Department of Comparative Biology \& Experimental Medicine, Faculty of Veterinary Medicine, \\ University of Calgary, Calgary, AB T2N 4N1, Canada; maria.arifin@ucalgary.ca (M.I.A.); \\ shannaou@ucalgary.ca (S.H.); shengchun.chang@ucalgary.ca (S.C.C.); sthapa@ucalgary.ca (S.T.); \\ hschaetz@ucalgary.ca (H.M.S.) \\ 2 Calgary Prion Research Unit, University of Calgary, Calgary, AB T2N 4N1, Canada \\ 3 Hotchkiss Brain Institute, University of Calgary, Calgary, AB T2N 4N1, Canada \\ * Correspondence: sgilch@ucalgary.ca
}

check for updates

Citation: Arifin, M.I.; Hannaoui, S.; Chang, S.C.; Thapa, S.; Schatzl, H.M.; Gilch, S. Cervid Prion Protein Polymorphisms: Role in Chronic Wasting Disease Pathogenesis. Int. J. Mol. Sci. 2021, 22, 2271. https:// doi.org/10.3390/ijms22052271

Academic Editor: Byung-Hoon Jeong

Received: 31 January 2021

Accepted: 22 February 2021

Published: 25 February 2021

Publisher's Note: MDPI stays neutral with regard to jurisdictional claims in published maps and institutional affiliations.

Copyright: (c) 2021 by the authors. Licensee MDPI, Basel, Switzerland. This article is an open access article distributed under the terms and conditions of the Creative Commons Attribution (CC BY) license (https:// creativecommons.org/licenses/by/ $4.0 /)$.

\begin{abstract}
Chronic wasting disease (CWD) is a prion disease found in both free-ranging and farmed cervids. Susceptibility of these animals to CWD is governed by various exogenous and endogenous factors. Past studies have demonstrated that polymorphisms within the prion protein $(\mathrm{PrP})$ sequence itself affect an animal's susceptibility to CWD. PrP polymorphisms can modulate CWD pathogenesis in two ways: the ability of the endogenous prion protein $\left(\mathrm{PrP}^{\mathrm{C}}\right)$ to convert into infectious prions $\left(\mathrm{PrP}^{\mathrm{Sc}}\right)$ or it can give rise to novel prion strains. In vivo studies in susceptible cervids, complemented by studies in transgenic mice expressing the corresponding cervid PrP sequence, show that each polymorphism has distinct effects on both $\mathrm{PrP}^{\mathrm{C}}$ and $\mathrm{PrP}^{\mathrm{Sc}}$. It is not entirely clear how these polymorphisms are responsible for these effects, but in vitro studies suggest they play a role in modifying $\operatorname{PrP}$ epitopes crucial for $\mathrm{PrP}^{\mathrm{C}}$ to $\mathrm{PrP}^{\mathrm{Sc}}$ conversion and determining $\operatorname{PrP}^{\mathrm{C}}$ stability. $\operatorname{PrP}$ polymorphisms are unique to one or two cervid species and most confer a certain degree of reduced susceptibility to CWD. However, to date, there are no reports of polymorphic cervid PrP alleles providing absolute resistance to CWD. Studies on polymorphisms have focused on those found in CWD-endemic areas, with the hope that understanding the role of an animal's genetics in CWD can help to predict, contain, or prevent transmission of CWD.
\end{abstract}

Keywords: chronic wasting disease; prion protein; cervid; polymorphism; strain; pathogenesis

\section{Introduction}

Chronic wasting disease (CWD) is a prion disease, or transmissible spongiform encephalopathy (TSE), found in cervid species, such as elk, deer, reindeer, and moose [1]. It is an infectious and fatal neurodegenerative disease with no prophylaxis or cure available [1]. Prions are proteinaceous infectious particles consisting of $\mathrm{PrP}^{\mathrm{Sc}}$, an abnormally folded and infectious isoform of the endogenous prion protein $\left(\mathrm{PrP}^{\mathrm{C}}\right)$. Prions can convert $\operatorname{PrP}^{\mathrm{C}}$ into $\mathrm{PrP} \mathrm{P}^{\mathrm{Sc}}$, leading to accumulation of aggregated $\mathrm{PrP}^{\mathrm{Sc}}$ in the central nervous system (CNS) and ultimately death [2]. Pronounced weight loss is a hallmark in animals with CWD, thus the term 'wasting disease' [1]. Another important feature of CWD is that CWD prions, abbreviated as PrPCWD here onwards, are very contagious [1]. This is because PrPCWD disseminates throughout the body of the infected cervid. PrPCWD has been detected in the lymphatic system, salivary gland, intestinal tract, muscles, and blood, as well as urine, saliva, and feces, of infected cervids [3-14]. PrPCWD is released into the environment through bodily fluids and excreta and bind to soil and plants, remaining infectious even after decades [15-19]. Prolonged $\mathrm{PrP}^{\mathrm{CWD}}$ shedding and its persistence in the environment leads to efficient lateral transmission between both farmed and free-ranging cervids $[10,14,20-23]$. 
CWD was first reported by the late E.S. Williams in captive mule deer in Colorado in the 1970s [24] and later on in free-ranging elk in 1981 [25]. In 1996, Saskatchewan reported the first case of CWD in Canada [26]. The disease was also reported in South Korea as a case of imported elk from Canada [27]. CWD is currently found in 26 U.S. states and 3 Canadian provinces (Figure 1) [28]. This efficient spread highlights the contagiousness and difficulty to contain CWD. Wild and farmed cervid species known to be naturally affected by CWD in North America include white-tailed deer (Odocoileus virginianus), mule deer (O. hemionus), elk (Cervus canadensis), red deer (C. elaphus), and moose (Alces alces sp.) [29]. In 2016, the first case of CWD in Europe was reported in free-ranging Norwegian reindeer (Rangifer tarandus tarandus), followed by reports in red deer and moose [30,31]. It was also recently reported in moose in Finland and Sweden (Figure 2) [32-34]. To date, the origin of CWD is not well known.

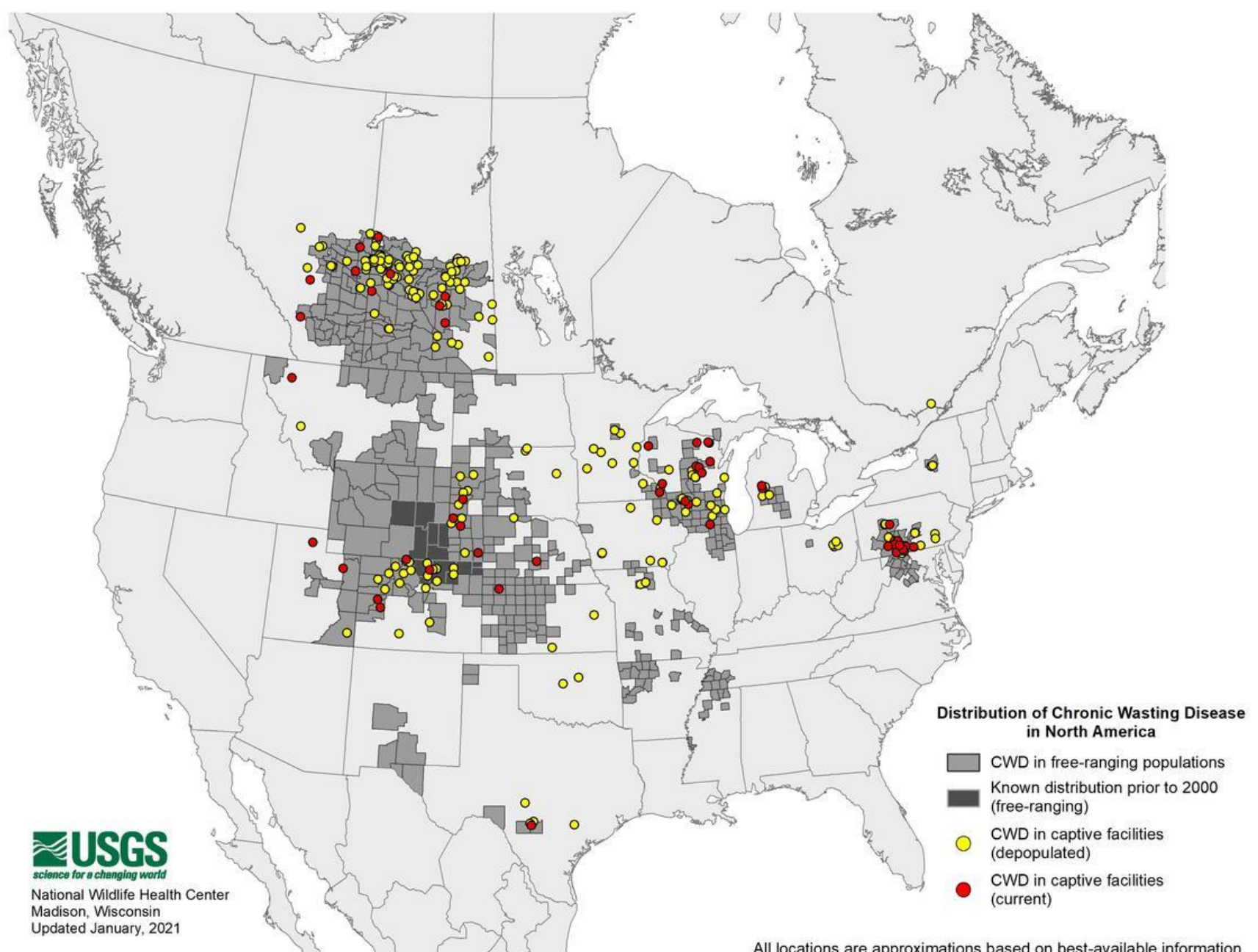

Figure 1. Chronic wasting disease (CWD) distribution in North America. Courtesy of the U.S. Geological Survey National Wildlife Health Center. 


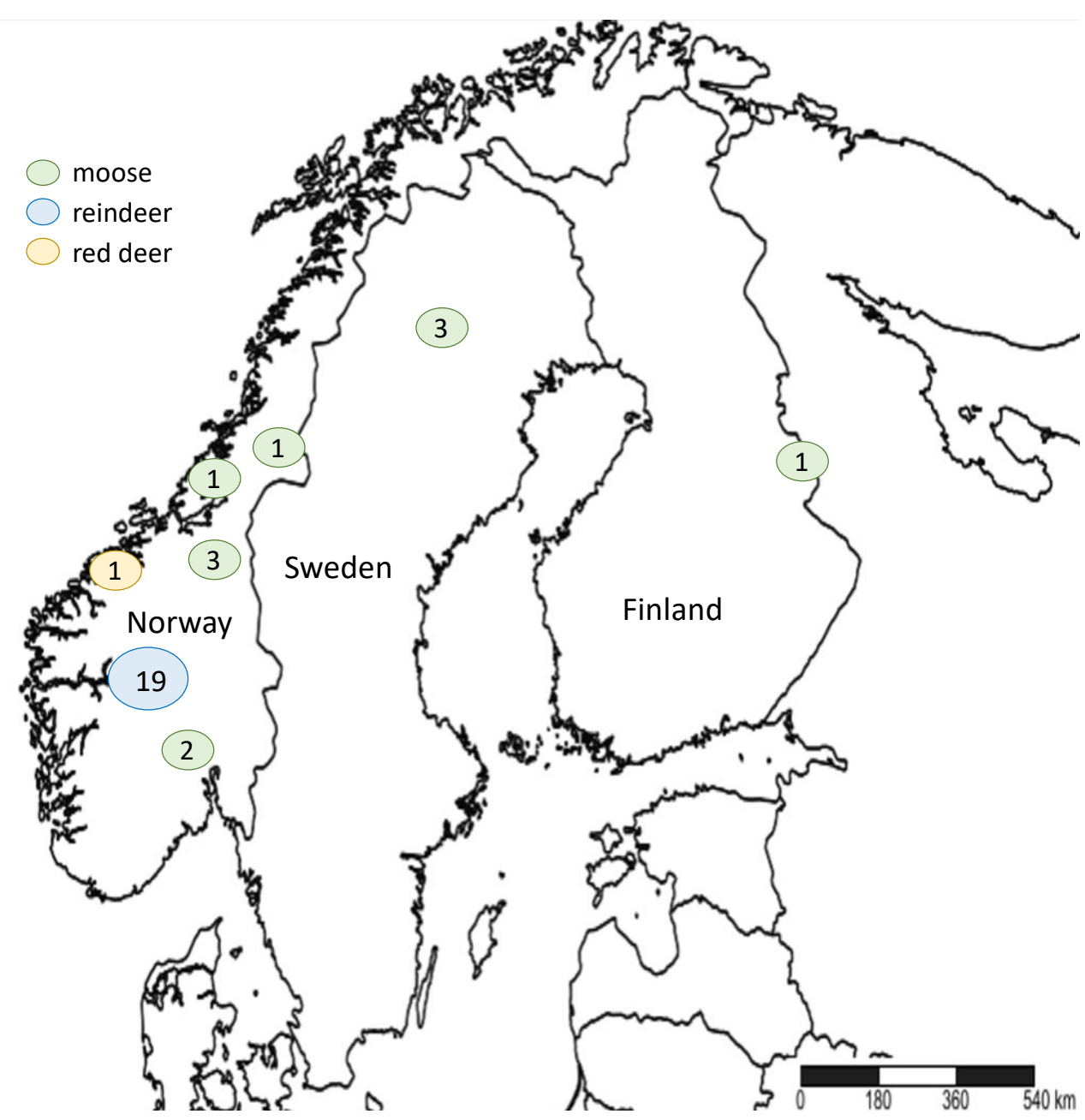

Figure 2. Chronic wasting disease (CWD) distribution in Scandinavia, based on Mysterud et al., 2020 [35]. Numbers in circles represent the number of CWD-positive animals.

While CWD is efficiently transmitted among and between cervid species, prions in general do not easily transmit from their main host species to other species due to the presence of transmission barriers [36-42]. The host's PrP primary sequence homology with the incoming $\mathrm{PrP}^{\mathrm{Sc}}$ is an important factor in the $\mathrm{PrP}^{\mathrm{C}}$ to $\mathrm{PrP}^{\mathrm{Sc}}$ conversion $[38,43-45]$. Mismatch between the substrate $\left(\mathrm{PrP}^{\mathrm{C}}\right)$ and template $\left(\mathrm{PrP}^{\mathrm{Sc}}\right)$ can result in less efficient conversion and hinder disease transmission [46-48]. Furthermore, the replication environment and presence of cofactors also play a role in successful prion propagation [49-56]. Studies show that different prion conformers or strains can propagate within a single host, resulting in a prion 'cloud' or isolate, containing a mixture of strains [57-60]. The prion strain concept is highly debated, but the generally accepted notion is that when a prion inoculum retains its disease phenotype in vivo and biochemical features in vitro through serial passages, it is recognized as a distinct strain [41,61-67]. However, prions can also 'jump' from one species to another, including zoonotic transmission. An important example of this phenomenon is bovine spongiform encephalopathy (BSE) that was transmitted to humans in the form of variant Creutzfeldt-Jakob Disease (vCJD) [68-70], as well as to a number of other species, e.g., exotic and domestic cats or exotic ungulates [71-77]. The molecular mechanisms of how prions adapt to a new host are not well understood. One possible mechanism is the selection of prion strain(s) preferred by the host $\mathrm{PrP}^{\mathrm{C}}$, enabling prion propagation $[78,79]$. Another is that the incoming $\mathrm{PrP}^{\mathrm{Sc}}$ can adapt to the host's $\mathrm{PrP}^{\mathrm{C}}$ conformation(s), or vice versa, sometimes resulting in the emergence of a new prion strain $[78,80,81]$. A 2019 study by Beringue and colleagues suggested that cross-species 
transmission can occur due to the cooperation between sub-assemblies of prion conformations $[82,83]$. One known molecular determinant or 'switch' of the CWD transmission barrier in this regard is the $\operatorname{PrP} \beta 2-\alpha 2$ loop [84-91]. Replacing the $\beta 2-\alpha 2$ loop sequence of different species with that of cervids resulted in increased misfolding of PrP and the transmissibility of CWD to these species [89-91]. Furthermore, it has been demonstrated that the prion transmission barrier can be modulated by non-synonymous single nucleotide polymorphisms (SNPs) within the prion protein gene (Prnp) [57,92,93]. In fact, selecting for prion-resistant Prnp alleles in breeding programs has been shown, or been predicted, to curb the spread of scrapie in sheep and goats [94-97]. Although the PrP sequence is highly conserved among cervid species (Figure 3), it has some variations [98,99]. Studies show that these polymorphisms contribute in modulating cervid susceptibility to CWD (Table 1) and $\operatorname{PrPCWD}$ strain propagation [93,99-101].

Table 1. Cervid prion protein polymorphisms reported to date.

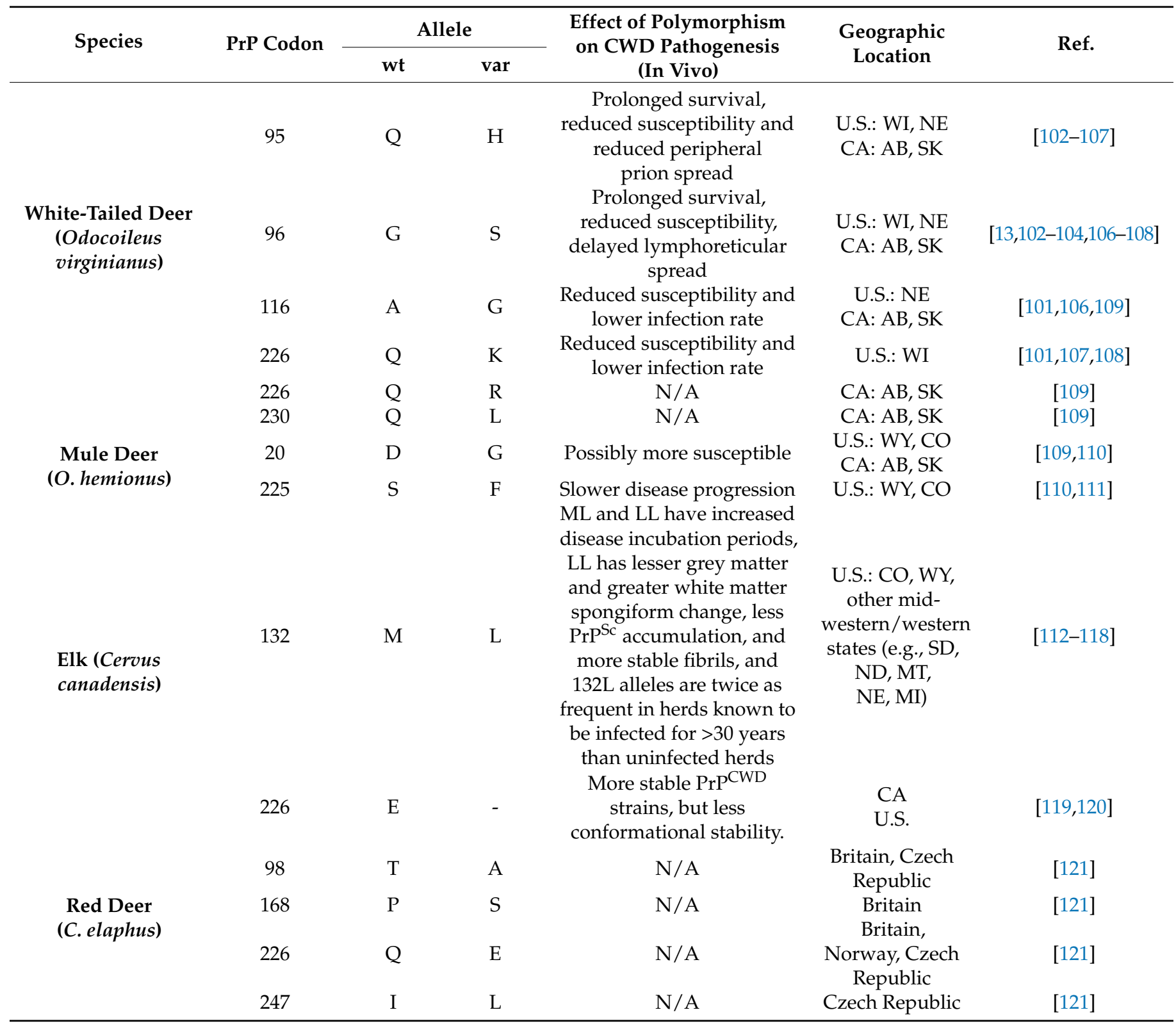


Table 1. Cont.

\begin{tabular}{|c|c|c|c|c|c|c|}
\hline \multirow{2}{*}{ Species } & \multirow{2}{*}{ PrP Codon } & \multicolumn{2}{|c|}{ Allele } & \multirow{2}{*}{$\begin{array}{c}\text { Effect of Polymorphism } \\
\text { on CWD Pathogenesis } \\
\text { (In Vivo) }\end{array}$} & \multirow{2}{*}{$\begin{array}{l}\text { Geographic } \\
\text { Location }\end{array}$} & \multirow{2}{*}{ Ref. } \\
\hline & & wt & var & & & \\
\hline $\begin{array}{l}\text { Sika Deer } \\
\text { (C. nippon) }\end{array}$ & 226 & $\mathrm{Q}$ & $\mathrm{E}$ & $\mathrm{N} / \mathrm{A}$ & Britain & [121] \\
\hline \multirow[t]{2}{*}{$\begin{array}{l}\text { Fallow Deer } \\
\text { (Dama dama) }\end{array}$} & 138 & $\mathrm{~N}$ & - & $\begin{array}{l}\text { Resistance to natural } \\
\text { infection and prolonged } \\
\text { incubation periods in } \\
\text { intra-cerebrally infected } \\
\text { animals }\end{array}$ & Britain & [122-124] \\
\hline & 226 & $\mathrm{E}$ & - & $\mathrm{N} / \mathrm{A}$ & Britain & [122-124] \\
\hline $\begin{array}{l}\text { Reeve's Muntjac } \\
\text { Deer (Muntiacus } \\
\quad \text { reevesii) }\end{array}$ & 98 & - & S & $\mathrm{N} / \mathrm{A}$ & Britain & [121] \\
\hline \multirow{2}{*}{$\begin{array}{l}\text { Chinese Water } \\
\text { Deer (Hydropotes } \\
\text { inermis inermis) }\end{array}$} & 100 & S & $\mathrm{N}$ & $\mathrm{N} / \mathrm{A}$ & Britain & {$[121]$} \\
\hline & $\mathrm{OR} *$ & 5 & 4 & $\mathrm{~N} / \mathrm{A}$ & Britain & {$[121]$} \\
\hline \multirow{5}{*}{$\begin{array}{l}\text { Korean Water } \\
\text { Deer }(\text { H. } i . \\
\text { argyropus) }\end{array}$} & 96 & G & $\mathrm{D}$ & $\mathrm{N} / \mathrm{A}$ & South Korea & [125] \\
\hline & 100 & $\mathrm{~N}$ & $S$ & $\mathrm{~N} / \mathrm{A}$ & South Korea & {$[125,126]$} \\
\hline & 170 & $\mathrm{D}$ & $\mathrm{G}$ & $\mathrm{N} / \mathrm{A}$ & South Korea & [125] \\
\hline & 36 & $\mathrm{~T}$ & $\mathrm{~N}$ & $\mathrm{~N} / \mathrm{A}$ & Canada & [98] \\
\hline & 100 & $\mathrm{~S}$ & $\mathrm{R}$ & $\mathrm{N} / \mathrm{A}$ & Canada & [127] \\
\hline \multirow[t]{4}{*}{ Moose (Alces sp.) } & 109 & K & $\mathrm{Q}$ & $\mathrm{N} / \mathrm{A}$ & Sweden & [98] \\
\hline & 209 & $\mathrm{M}$ & $\hat{\mathrm{I}}$ & $\mathrm{N} / \mathrm{A}$ & U.S.: WY, WK & {$[128,129]$} \\
\hline & 2 & $\mathrm{~V}$ & M & $\mathrm{N} / \mathrm{A}$ & $\begin{array}{c}\text { CA } \\
\text { U.S.: AK }\end{array}$ & [130-132] \\
\hline & 129 & G & S & $\mathrm{N} / \mathrm{A}$ & $\begin{array}{c}\text { CA } \\
\text { U.S.: AK }\end{array}$ & {$[130,131,133]$} \\
\hline \multirow[t]{7}{*}{$\begin{array}{l}\text { Caribou/Reindeer } \\
\text { (Rangifer tarandus } \\
\text { sp.) }\end{array}$} & 138 & S & $\mathrm{N}$ & $\begin{array}{l}\text { 138SN and NN reindeer } \\
\text { have prolonged incubation } \\
\text { periods in oral } \\
\text { transmission, and both } \\
\text { also have no or limited } \\
\text { PrPCWD distribution in the } \\
\text { CNS }\end{array}$ & $\begin{array}{c}\text { CA: BC, YK, } \\
\text { NT, AB, SK } \\
\text { U.S.: AK }\end{array}$ & {$[130,131,133,134]$} \\
\hline & 153 & $\mathrm{Y}$ & $\mathrm{F}$ & $\mathrm{N} / \mathrm{A}$ & $\mathrm{CA}$ & [133] \\
\hline & 169 & $\mathrm{~V}$ & $\mathrm{M}$ & $\mathrm{N} / \mathrm{A}$ & $\begin{array}{c}\text { CA } \\
\text { U.S.: AK }\end{array}$ & {$[130,131,133]$} \\
\hline & 176 & $\mathrm{~N}$ & $\mathrm{D}$ & $\mathrm{N} / \mathrm{A}$ & $\begin{array}{l}\text { Sweden, } \\
\text { Norway } \\
\text { CA: NWT }\end{array}$ & {$[98,133]$} \\
\hline & 225 & S & $\mathrm{Y}$ & Higher risk of infection & $\begin{array}{l}\text { Sweden, } \\
\text { Norway }\end{array}$ & {$[98,135]$} \\
\hline & 242 & $\mathrm{P}$ & $\mathrm{L}$ & $\mathrm{N} / \mathrm{A}$ & $\mathrm{CA}$ & [133] \\
\hline & OR & 5 & 4 & Higher risk of infection & Norway & [135] \\
\hline
\end{tabular}

\section{Prnp Polymorphisms in Cervids}

The Prnp coding sequence is extremely conserved among cervid species (Figure 3); however, there are numerous key polymorphisms that have been identified and, for some, well-characterized that they are associated with lower rates and/or delayed CWD disease progression (Table 1). Very early on, even when CWD was not as widespread as today, genetic analyses suggested the existence of a polymorphism at codon 132 in the North American elk PrP sequence that encodes either methionine (M) or leucine (L), with the $132 \mathrm{M}$ being the more frequent (wild-type) allele [112]. This report was of interest because codon 132 in elk is equivalent to codon 129 in the human PRNP which encodes either M or valine (V). Codon 129 in the human PRNP has been described as a key polymorphism 
influencing susceptibility to prion diseases [137,138], and more particularly, to the BSE agent. Shortly after, O'Rourke and colleagues confirmed the existence of this dimorphism in elk [139], and they reported that 132M homozygotes were over-represented in free-ranging, as well as farmed elk infected with CWD, when compared to healthy animals. Based on that, they suggested, for the first time, the existence of a relative protection of animals carrying at least one allele encoding $L$ at codon 132 (132LL and 132ML) against CWD [113]. This suggestion was later conflicted by a study of Perucchini and colleagues who instead showed that in a survey of free-ranging elk in Colorado, each genotype was represented in CWD-positive animals in proportion to their frequency in the population [116]. However, the protective effects against CWD-infection of 132L have been validated in an experimental setting [114,115]. To compare the genetic susceptibility of elk, Hamir and colleagues have orally challenged elk with 132MM, 132ML, or 132LL genotypes with brain material from a pool of 132MM and 132ML elk infected with CWD [114]. The results of this study suggested that 132LL elk may have reduced susceptibility to oral infection with CWD as they did not develop disease up to the point when 132MM and 132ML animals developed clinical signs of disease, though there was a significant difference in incubation time between the latter two, as well [114]. Shortly after, the same group reported that 132LL animals were indeed susceptible to CWD infection but with incubation periods approximately 1.5 times longer than 132ML elk and 3 times longer than those homozygous for 132M [115]. Compared to 132MM, disease in 132LL elk was characterized by differences in spongiform changes, $\mathrm{PrP} C W D$ distribution and accumulation, and higher $\operatorname{PrP} \mathrm{PWD}^{\mathrm{CW}}$ fibril stability, which led to a significant negative correlation between relative amount of $\mathrm{PrP}^{\mathrm{CWD}}$ and incubation periods [115]. A recent study from the same group confirmed that these characteristics were retained in passages in transgenic mice expressing 132L elk PrP [140].

Comparisons of the Prnp coding sequence of mule deer and Rocky Mountain elk revealed that these two species have identical PrP sequences, with the exception of codon 226 that encodes glutamic acid (E) in elk and glutamine (Q) in mule deer [119]. Extensive genetic analyses revealed the presence of a polymorphism at codon 20 of the mule deer sequence, which encodes either aspartate $(\mathrm{D})$ or glycine $(\mathrm{G})$, and at position 225 , encoding serine (S) or phenylalanine (F), with a frequency of 0.85 of the dominant alleles (D20 and S225) [141]. Jewell and colleagues showed that the infection rate of CWD was 30 times higher in mule deer homozygous for $\mathrm{S}$ at position 225 compared to heterozygous animals (225SF) in the CWD endemic areas of Wyoming and Colorado [110]. In fact, while the combined frequency of heterozygous 225SF and homozygous 225FF mule deer was $9.3 \%$, these animals represent only $0.3 \%$ of the sampled population that developed CWD [110]. Another study conducted on 19 mule deer orally challenged with CWD and followed from 3 to 26 months after inoculation showed that peripheral and central PrPCWD accumulation and deposition were comparable between 225SS and 225SF mule deer at the terminal stage of disease (19 to 23 and 36 months post-infection, respectively). However, the time course of $\mathrm{PrP}^{\mathrm{CWD}}$ distribution was significantly different between the different genotypes (SS vs. SF). In $225 \mathrm{SF}$ animals, deposition of $\mathrm{PrP}^{\mathrm{CWD}}$ in lymphatic tissues and in the CNS was significantly delayed compared to 225SS animals. In fact, 225SS mule deer developed spongiform lesions after approximately 19 months post-infection, while 225SF animals were still asymptomatic, without any neuropathological lesions for up to 25 months postinfection [111]. Later studies showed that CWD susceptibility in mule deer with different Prnp genotypes at position 225 was also different. Though all animals (SS and FF) became infected with CWD, clinical disease manifestations were more subtle and detection of $\mathrm{PrP}^{\mathrm{CWD}}$ with standard methods was inconclusive in 225FF mule deer, with presence of spongiform encephalopathy and the absence of detectable PrPCWD deposits in the brain [142]. Apart from this, CWD in 225FF animals, in general, presented a more subtle, atypical trait and negative PrPCWD immunoreactivity in the lymph nodes and obex [142]. Subsequent studies in transgenic mice expressing 225F-mule deer $\operatorname{PrP}^{\mathrm{C}}$ further confirmed the effects of this polymorphism on CWD susceptibility [42]. 
The presence of a universally processed, but unexpressed, pseudogene (Prnp $\psi$ ) encoding asparagine $(\mathrm{N})$ at codon 138 was initially reported in mule deer [141]. This complicated the analysis of genetic susceptibility of mule deer to CWD infection because the primers used failed to discriminate between the functional Prnp from Prnp $\psi$. O'Rourke and colleagues confirmed the presence of the Prnp $\psi$ pseudogene in a study conducted in Nebraska of captive white-tailed deer [106]. They identified two alleles in the pseudogene encoding five or six copies of the octapeptide repeat, both of which encode $\mathrm{N}$ at codon 138 [106]. Later on, it was shown that the polymorphism at codon 138 was not unique to the Prnp $\psi$ pseudogene but was also a feature of the functional Prnp gene in certain cervid species. Fallow deer are all homozygous for $\mathrm{N}$ at codon 138 [122]. Reindeer/caribou are found to also carry the S138N polymorphism, but not mule deer and white-tailed deer $[122,123,131]$. The $138 \mathrm{~N}$ allele is present in caribou herds in North America in frequencies between 0.2-0.64 depending on population and subspecies, but it has not been reported in wild reindeer in Norway [130,132,133,135]. Interestingly, a significantly higher frequency of the $138 \mathrm{~N}$ allele was detected in barren-ground compared to woodland caribou herds, with the exception of the Chinchaga woodland population [132,133]. The presence of the $138 \mathrm{~N}$ allele was shown to be associated with reduced susceptibility to CWD upon natural routes of infection $[123,124,131,134]$. Fallow deer, which are homozygous for $\mathrm{N}$ at position 138, were resistant to natural CWD infection, suggesting that the presence of the $138 \mathrm{~N}$ allele confers a relative protection, or, at least, delays the progression of the disease in this species. However, considering that intracerebral (i.c.) inoculation resulted in CWD infection, albeit with prolonged survival times [123], this shows that $138 \mathrm{~N} \mathrm{PrPC}^{\mathrm{C}}$ can be converted to PrPCWD in vivo and, thus, does not confer an absolute protection against CWD. In parallel, Mitchell and colleagues also showed that the polymorphism at position 138 influences reindeer susceptibility to CWD upon oral infection [131]. They first suggested that homozygosity for $\mathrm{S}$ at codon 138 of the reindeer Prnp gene was associated with susceptibility to the CWD agent, while the presence of one $138 \mathrm{~N}$ allele conferred resistance against it [131]. Later on, it was shown in another study that reindeer carrying the $\mathrm{N}$ allele eventually developed disease upon natural CWD infection [134]. However, PrPCWD distribution in 138SN or $\mathrm{NN}$ animals was mostly limited to lymphoid tissues with significantly lower $\mathrm{PrP}^{\mathrm{CWD}}$ burden compared to 138SS animals [134]. To further prove this, our lab has generated and inoculated gene-targeted mice expressing wt and 138N-cervid PrP through i.c. and intraperitoneal (i.p.) routes with various PrPCWD isolates. $138 \mathrm{NN}$ mice did not develop clinical disease (up to $\pm 660 \mathrm{dpi}$ ), while their 138SS (wt) PrP counterparts succumbed to disease at \pm 450 dpi upon i.c. inoculation, with confirmatory protease resistant $\operatorname{PrP}\left(\mathrm{PrP}^{\mathrm{res}}\right)$ on immunoblot (unpublished data). 


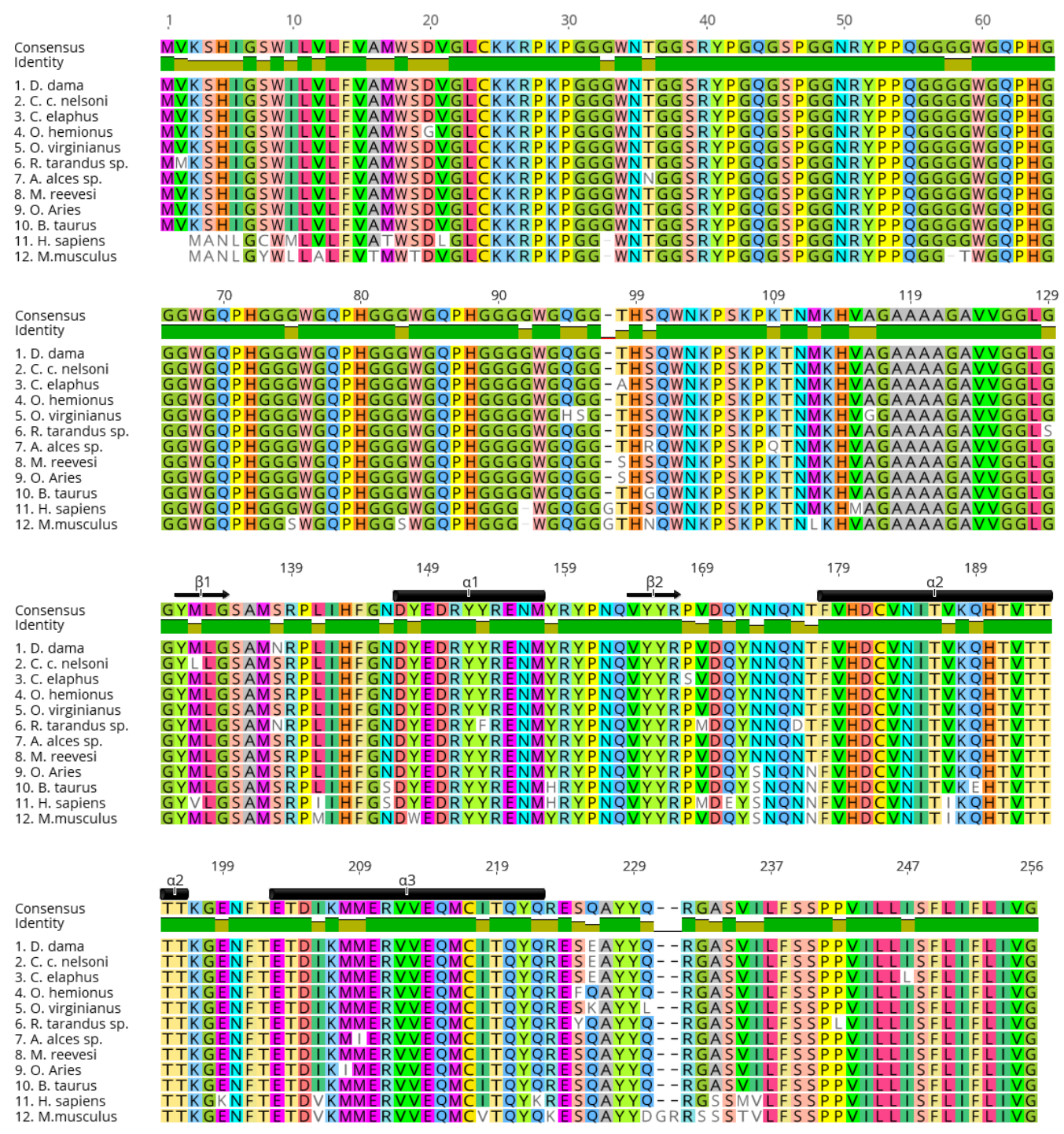

Figure 3. Cervid prion protein sequence alignment showing conserved homology between species. Protein alignment was performed in Geneious v10.2.6 (https:/ / www.geneious.com) (accessed on 15 December 2020) using the ClustalW algorithm. Amino acid numbering is based on the consensus sequence. Amino acid variants were added manually to each sequence and are shown in white boxes. NCBI accession numbers used in this alignment: (1) QAU19527.1, (2) ABW79881.1, (3) QAU19537.1, (4) AAO91945.1, (5) QKI87491.1, (6) AAT77253.1, (7) QHZ32187.1, (8) AGU92564.1, (9) ABA08026.1, (10) BAI50003.1, (11) BCK59655.1, (12) CAJ18553.1. $\beta 1, \beta 2$ : first, second beta-strand; $\alpha 1, \alpha 2, \alpha 3$ : first, second and third alpha-helix (based on mouse PrP numbering [136]). Refer to Table 1 for cervid species names in sequences 1-8. Non-cervid species names for sequences 9-12: O. = Ovis, B. = Bos, H. = Homo and M. = Mus.

O'Rourke and colleagues confirmed previous studies done in smaller cohorts [39,102,143] by determining the Prnp genotypes and CWD status in a group of 113 captive white-tailed deer (WTD) in west Nebraska [106]. In this study, half of the WTD tested for PrPCWD were positive in the brainstem or lymphoid tissues and three SNPs in Prnp were identified, at position 95 with alleles encoding either glutamine $(Q)$ or histidine $(H)$, at position 96 encoding either $G$ or $S$ and at position 116 encoding alanine (A) or G. A study by Johnson and colleagues in Wisconsin free-ranging WTD comparing the Prnp genotypes of CWD-positive and -negative WTD to determine the impact of gene modulation on CWD susceptibility revealed a polymorphism in the WTD Prnp gene at position 226 encoding either Q or lysine (K) [103]. Most importantly, by comparing the allelic frequencies of CWD-affected and CWD-negative WTD, they suggested that the presence of H and S at codon 95 and 96, respectively, was associated with reduced susceptibility to CWD [103]. 
However, although the presence of the $96 \mathrm{~S}$ allele among CWD-infected deer was associated with slower disease progression and decreased $\mathrm{PrP}^{\mathrm{CWD}}$ deposition compared to animals homozygous for $96 \mathrm{G}$, the $96 \mathrm{~S}$ animals were not completely resistant to the CWD agent as a CWD-affected homozygous 96S WTD was identified in this study [103]. Others reported a reduced CWD prevalence linked to the presence of the $96 \mathrm{~S}$ allele $[108,144]$ and that WTD homozygous for 96G had a four times greater risk of CWD infection [144]. Although the occurrence of the $95 \mathrm{H}$ allele is very rare (1-2\%) in wild WTD population, the fact that animals carrying this allele are affected by CWD at an even lower rate in proportion to its allelic frequency suggests that it confers a relative protection against CWD [101,103,106,109,145]. In an experimental study, WTD with different Prnp alleles, wt (95Q/96G), 96S/wt (96S/95Q), 95H/wt (95H/96G), or 95H/96S were inoculated orally with PrPCWD originating from wt (95Q/96G) WTD, to test the effect of the Prnp polymorphism on CWD susceptibility [105]. While all inoculated WTD succumbed to clinical CWD, a remarkable difference was observed in average survival periods between inoculated WTD harboring wt and other Prnp genotypes [105]. Wild type CWD-affected WTD had an average survival of less than 2 years, while 96S/wt CWD-affected WTD succumbed 9 months later [105]. Interestingly, WTD carrying the 95H allele showed the longest survival for up to 2.5 years post-infection [105]. Further analysis showed altered peripheral prion distribution in the $95 \mathrm{H}$ animals [105]. Changes in the biological and biophysical properties demonstrated the emergence of a new $\operatorname{PrP} \mathrm{PWD}^{\mathrm{CW}}$ strain, later referred to as $95 \mathrm{H}^{+}[93,104,146,147]$. The effects of these polymorphisms were faithfully reproduced in wt $96 \mathrm{G}$ or $96 \mathrm{~S}$ transgenic mice $[42,148,149]$.

Another polymorphism with a very low frequency in the wild population is the A116G polymorphism in WTD. Although its influence on CWD susceptibility is unclear, with either no effect [106] or potential reduced susceptibility [92], this polymorphism is of certain interest because of its position in the highly conserved central hydrophobic core (HC) domain of PrP that is involved in prion conversion [150-153]. It is equivalent to codon 113 in human PRNP, located in the HC domain where other mutations are responsible for heritable prion disease [154].

In North American moose (Alces alces spp), polymorphisms at position 36, encoding threonine $(\mathrm{T})$ or $\mathrm{N}$, at position 100 encoding either $\mathrm{S}$ or arginine (R), and at position 209 encoding either M or isoleucine (I) have been reported [98,127,129]. The PrP sequence of European moose ( $A$. a. alces) has high homology to the North American moose with the exception of the variant $\mathrm{K}$ to $\mathrm{Q}$ at position 109 [98]. All CWD cases identified to date were in moose carrying the wild type PrP sequence [32]. However, CWD-positive cases in moose are rare compared to other cervids; therefore, it is not possible to draw conclusions about how these polymorphisms could modulate CWD susceptibility.

\section{Cervid PrP Polymorphisms and Effects on $\operatorname{PrP}^{\mathrm{C}}$ Structure}

There is strong evidence demonstrating that cervid Prnp polymorphisms can affect susceptibility to CWD, raising the question how these single amino acid substitutions affect $\mathrm{PrP}^{\mathrm{C}}$ folding. Studies utilizing in silico molecular dynamics (MD) simulation, as well as high-resolution structure data obtained from nuclear magnetic resonance (NMR) spectroscopy, have provided valuable biophysical information; however, only a very limited number of the known polymorphisms were analyzed.

An interesting feature of the cervid PrP structure is that the loop between the second $\beta$-sheet ( $\beta 2)$ and second $\alpha$-helix ( $\alpha 2)$ is extremely well defined, which makes it more rigid compared to other species, due to amino acid substitutions from $\mathrm{S}$ to $\mathrm{N}$ at position 170 , and $\mathrm{N}$ to threonine (T) at position 174 (Figure 3; mouse PrP numbering) [84,90]. Overexpression of the S170N/N174T or 'rigid loop' PrP in transgenic mice has been shown to induce spontaneous de novo prion disease [84]. Furthermore, this structure also plays a key role in $\mathrm{PrP}^{\mathrm{CWD}}$ transmissibility to different species, including to humans $[85,87,155,156]$.

The distal region of the third $\alpha$-helix ( $\alpha 3$ ) is known to interact with the $\beta 2-\alpha 2$ loop, resulting in a protein surface epitope that affects the conversion of $\operatorname{PrP}^{\mathrm{C}}$ to $\operatorname{PrP}^{\mathrm{Sc}}[42,88,157]$. 
Interestingly, when the $\beta 2-\alpha 2$ loop of mouse PrP is replaced with the S170N/N174T rigid loop, the $\alpha 3$ helix up to codon 226 also becomes more well defined [88]. Recent studies using MD simulations to explore the effects of substituting amino acids at codons 225 and 226 in cervid PrP show that a F and $Q$ at these respective positions, which represents the 225F PrP allele found in mule deer less susceptible to CWD infection, allows for the formation of side chain hydrogen bonds between the tyrosine (Y) at codon 228 of the $\alpha 3$ helix and the aspartate (D) at codon 170 of the $\beta 2-\alpha 2$ loop, thus likely resulting in a more stable structure [42].

MD simulations on wt 116A and 116G WTD PrP revealed that the latter has a less stable conformation, based on several parameters. The 116G PrP conformer, when compared to the wt conformer, has greater structural fluctuations and is less compact with a larger radius of gyration [92]. The $116 \mathrm{G}$ conformer also has a greater propensity to form $\beta$-strands, where in the rigid loop and portions of the hydrophobic domain it has a higher proportion of $\beta$-strand secondary structure [92]. In addition, this polymorphic variant has a slightly larger solvent accessible surface area and hydrophobic residue exposure, indicating a weaker solvent-residue interaction, thus predisposing the structure to self-assembly [92]. These in silico findings are corroborated by real-time quaking induced conversion assays (RT-QuIC), a sensitive cell-free prion amplification technique involving the successive cycles of shaking and incubating the prion seed in a mixture of recombinant $\operatorname{PrP}(\mathrm{rPrP})$ and Thioflavin $\mathrm{T}$ that fluoresces upon binding to amyloid aggregates [158]. When using 116G or 116A rPrP substrates and CWD-infected brain homogenate from WTD as a seed, 116G rPrP exhibited a higher conversion rate [92,159]. Regarding elk Prnp polymorphisms, the 132L substrate had lower amplification rates and extension efficiency than that of $132 \mathrm{M}$ and wild-type deer substrates [159]. However, it needs to be determined whether this accelerated conversion in vitro translates into an in vivo situation. Similar MD analyses was performed on the 96S and 95H WTD PrP polymorphisms, both associated with reduced susceptibility to CWD infection. These studies indicated that $96 \mathrm{~S} \operatorname{PrP}$ is less stable than wt and $95 \mathrm{H}$ conformers, which were similar [160].

Overall, studies investigating structural effects and the impact of polymorphisms on aggregation and conversion propensity are very limited. More work is needed to identify correlations between PrP stability and CWD susceptibility.

\section{Prion Protein Polymorphisms and PrPCWD Strains}

As previously mentioned, prions exist as different conformers, to which we refer as strains. The strain phenomena can occur spontaneously, or due to mutation and selection during the process of adaptation in a new host [57]. The presence of prion strains was first reported in goats [161,162] and later on in other species, including cervids [163]. A prion strain is considered a distinct strain when they present consistent biological and biochemical characteristics, e.g., stability in denaturing agents, distribution in the CNS, tropism in different tissues, incubation period in vivo, and retain these features upon serial passage in animal models $[41,64,66,67,164]$.

Angers and colleagues reported the first presence of $\mathrm{PrPCWD}^{\mathrm{CW}}$ strains in both deer and elk, identified as CWD1 and CWD2 [163]. First and second passages of these isolates into transgenic mice overexpressing deer $\operatorname{PrP}(\mathrm{Tg}(\mathrm{CerPrP}) 1536)$ show that each strain retained its distinct characteristics, i.e., differences in disease incubation times and neuropathological profiles [163]. However, elk seemed to propagate more distinctly CWD1 or CWD2 strains compared to a more 'mixed' phenotype in deer [163]. Transmission into transgenic mice expressing elk PrP [165] indicated that expressing the 226E allele results in more stable strains, whereas the 226Q deer PrP generates unstable strains resulting in less distinguishable phenotypes with subsequent passages. This indicates that the host's PrP plays a role in determining how the strains are being propagated in these transgenic mice [163]. The effect of these residues was later confirmed in gene-targeted mice expressing deer (GtQ226) or elk (GtE226) PrP [120]. 
Protein conformational stability, which is determined by denaturation with guanidium hydrochloride, can be used to distinguish prion variants [166]. This readout revealed that the 226Q deer PrPCWD has a greater conformational stability than that of the elk (226E), demonstrated in the GtE226 and GtQ226 mice [120], as well as CWD-infected RK13 cells [167]. In mule deer PrP, where 225F is known to be the less susceptible allele, studies suggest the possibility of a different strain [42]. $\mathrm{PrPSc}^{\mathrm{Sc}}$ distribution patterns in $\operatorname{tg}$ DeerPrP-F225 mice were altered compared to inoculated tgDeer mice. TgDeerPrP-F225 mice showed diffuse and more widespread PrPCWD deposition in the thalamus but not the corpus callosum, while inoculated tgDeer (wt) mice were characterized by continuous, symmetrical plaque deposits throughout the hippocampal alveus [42].

The impact of the elk M132L polymorphism was assessed in in vitro and in vivo studies. Using 132L rPrP as a substrate in RT-QuIC resulted in longer lag times (time to reach the positivity threshold) compared to $132 \mathrm{M}$ substrate seeded with PrPCWD from 132MM or ML animals [118]. These in vitro data, together with the in vivo studies in both elk and mice mentioned above $[115,118]$, indicated that CWD-infected elk with various genotypes may carry distinct prion strains. Strain typing experiments have been carried out using transgenic mouse models expressing M132 or L132 elk prion protein [140], strengthening the argument that this Prnp polymorphism modulates the isolation of a novel PrPCWD strain.

Transgenic mice expressing wt-deer $\mathrm{PrP}^{\mathrm{C}}(\operatorname{tg} 33)$ or $96 \mathrm{~S} \mathrm{PrPC}^{\mathrm{C}}(\operatorname{tg} 60)$ were generated to assess the effects of the polymorphism at position 96 [148]. Tg33 mice developed disease as early as $160 \mathrm{dpi}$ when challenged with $\mathrm{PrPCWD}$, with typical vacuolation and deposition of PrPCWD in the brain [148]. Some animals showed extensive neuronal loss and apoptosis in the hippocampus and cerebellum, and extraneuronal $\mathrm{PrPCWD}$ accumulation was found in the spleen and intestinal tissue [148]. In contrast, inoculated tg60 mice did not show any evidence of prion disease nor propagation of $\mathrm{PrPCWD}$ at over $600 \mathrm{dpi}$ [148]. When the same lines were inoculated with CWD-affected 96SS deer brain homogenate, $\operatorname{tg} 33$ mice developed clinical signs of disease and succumbed to the 96SS prions, while tg60 inoculated mice were not susceptible to the same inoculum [149]. Interestingly, tg60 mice inoculated with brain homogenate from inoculated tg33 mice showed no transmission suggesting that 96S PrP played an inhibitory role in disease progression in these mice [149]. In addition, heterozygous mice were generated by breeding homozygous 96G and 96S mice and challenged with $\operatorname{PrP}^{C W D}$ [149]. Heterozygosity resulted in delayed disease in these mice, once again showing that, although it does not provide complete resistance, this allele plays an important role in CWD susceptibility [149]. In fact, transgenic mice, $\operatorname{tg}(\mathrm{DeerPrP}$ S96), overexpressing 96S-deer PrP, and tg(DeerPrP-H95) were generated and challenged with different prion agents [42]. As expected, substitutions at residues 95 and 96 inhibited PrPCWD propagation [42]. All challenged tg(H95) animals remained free of clinical signs, while $\operatorname{tg}$ (S96) animals showed an incomplete attack rate with delayed incubation times [42]. It, therefore, appears that substitutions in the unstructured region of PrP, at residues 95 and 96 affect prion conversion in a strain/species-specific manner. However, in Angers' study [42], $\operatorname{tg}($ S96) mice were only partially resistant to PrPCWD and this somewhat conflicts the tg60 studies that showed a complete resistance to PrPCWD $[148,149]$. Furthermore, deer homozygous for 965 were found to be susceptible to CWD [108], which corroborates Anger's findings. For this reason, the complete resistance of tg 60 mice to $\mathrm{PrPCWD}^{\mathrm{CW}}$ was imputed to the low transgene expression in these mice (70\% of physiological expression), but it was later demonstrated otherwise [93]. Tg60 mice succumbed to prion disease only when inoculated with PrPCWD from deer expressing the $95 \mathrm{H}$ allele $(95 \mathrm{H} / 95 \mathrm{Q}$ and $95 \mathrm{H} / 96 \mathrm{~S})$. Incubation periods in diseased tg60 mice decreased upon passages suggesting an adaptation of the $95 \mathrm{H}^{+} \mathrm{PrPCWD}$ agent. These series of experiments revealed that $95 \mathrm{H}^{+}$was an emergent strain that adapted when passaged in mice expressing 96S-PrP, confirming once again that Prnp polymorphisms modulate the emergence and selection of novel strains [93]. In addition to transmissions in wt and 96S-PrP mice, $95 \mathrm{H}^{+}$prions were also proven to be different following transmission into Syrian golden hamsters and C57BL/ 6 
mice $[146,147]$. In fact, $95 \mathrm{H}^{+}$only induced clinical disease in C57BL/ 6 but not in hamsters. Similarities between conformational stabilities of $\operatorname{PrP}^{C W D}$ from the brains of $95 \mathrm{H}^{+}-\operatorname{tg} 60$ mice and $\mathrm{PrP} \mathrm{PWD}^{\mathrm{CW}}$ from brains of $95 \mathrm{H} / 96 \mathrm{~S}$ deer revealed that the $95 \mathrm{H}^{+}$strain was in fact a product of the replication of Wisc-1 ( $\mathrm{PrP}^{\mathrm{CWD}}$ originating from a wt WTD field isolate) by 95H-PrPC [147].

We have characterized the impact of a polymorphism at codon 116 (A to G) of the WTD PrP on $\operatorname{PrP}^{\mathrm{C}}$ and $\mathrm{PrP} \mathrm{CWD}^{\mathrm{CWD}}$ properties and susceptibility [92]. We compared $\mathrm{PrP}^{\mathrm{CWD}}$ obtained from a heterozygous 116AG hunter-harvested wild deer to that of the Wisc-1 wt WTD isolate. When $\operatorname{tgDeer}\left(\operatorname{tg}(\mathrm{CerPrP}) 1536^{+/+}\right)$mice were inoculated with either wt 116AA (Wisc-1) or 116AG prions, mice showed significant differences in terms of disease progression and survival [92]. Wisc-1 inoculated mice had a rapid disease progression and short survival compared to 116AG-inoculated mice, which had a delayed disease progression by approximately 2 months and prolonged survival [92]. Upon subsequent passages, inoculated $\mathrm{PrPCWD}$ adapted to their new host (tgDeer) with shortened survival, but disease progression and survival times were still significantly different between the two $\operatorname{PrP} \mathrm{P}^{\mathrm{CWD}}$ isolates [92]. Furthermore, distinct biochemical features of the two $\operatorname{PrP}^{\mathrm{CWD}}$ isolates were retained upon passage in tgDeer mice. Tg60 mice inoculated with the 116AG isolate succumbed to prion disease with a survival time and biochemical signature different from that of $95 \mathrm{H}^{+}$, the only $\mathrm{PrP}^{\mathrm{CWD}}$ strain previously known to induce disease in tg60 mice (unpublished data). This finding strongly suggests that $95 \mathrm{H}^{+}$and $116 \mathrm{AG}$ are distinct $\mathrm{PrP}^{\mathrm{CWD}}$ strains. 116AG PrPCWD derived from deer brain samples were also found to be conformationally less stable than the wild type 116AA PrPCWD [92]. Primary cerebellar granular neuron (CGN) cultures generated from tgDeer mice [168] were found to facilitate improved propagation of 116AA over 116AG PrPCWD [92]. RT-QuIC assay also showed that 116AG PrP ${ }^{C W D}$ have reduced seeding activity compared to 116AA PrPCWD; however, 116G rPrP forms amyloid fibrils in vitro more readily than 116AA rPrP [92]. All together, these results strongly support the existence of a new distinct strain, 116AG that is different from Wisc- 1 and $95 \mathrm{H}^{+} \mathrm{PrPCWD}^{\mathrm{CW}}$ strains. Our findings suggest that the presence of the $116 \mathrm{AG}$ $\mathrm{PrP}^{\mathrm{CWD}}$ may strongly impact the replication of the wt/Wisc1 $\mathrm{PrP}^{\mathrm{Sc}}$. While it is still unclear how 116AG strains were generated, novel strains with such specific characteristics might impact the ability of $\mathrm{PrP}^{\mathrm{CWD}}$ to cross species barriers among cervid and non-cervid species.

\section{5. $\operatorname{PrP}^{\mathrm{CWD}}$ Shedding in Cervid Species}

PrPCWD are highly contagious as these prions, either amplified in the CNS and anterogradely transported to the periphery, or amplified in these extraneural organs themselves, are shed through excrements and bodily fluids (feces, urine, saliva, blood, etc.) of infected cervids [3,8,11-14,169-172]. This facilitates direct transmission by animal contacts, as well as indirect transmission through contaminated soil and foliage, followed by transport to the CNS through peripheral nerves, typically those innervating organs of the digestive and lymphatic system $[169,173-177]$. In addition, transmission by blood transfusion and the placenta have been shown $[178,179]$. The infectious dose of $\operatorname{PrP}^{\mathrm{CWD}}$ in saliva and urine of infected deer and transgenic mice was determined in several studies $[6,10,180]$. Saliva seemed to be the most infectious material in infected cervids, with $\mathrm{PrP}^{\mathrm{CWD}}$ concentrations similar to $10^{-6}$ to $10^{-8} \mathrm{CWD}$-positive brain dilutions and 10-fold than that of urine $[10,180]$. The critical question arises whether prolonged shedding occurs due to polymorphisms affecting susceptibility to CWD. Although few studies have been done to investigate the effect of cervid PrP polymorphisms on PrP ${ }^{C W D}$ shedding, some indicate that differences do occur $[8,10,14,99,101,111,181,182]$. Plummer and colleagues suggested that less susceptible cervid Prnp genotypes, such as 132ML in elk, 225SF in MD and 96SS in WTD, shed less $\mathrm{PrP}^{\mathrm{CWD}}$ in their urine and feces [181], in agreement with other studies [11,14]. However, other studies also investigating the G96S polymorphism reported little difference in PrPCWD detection in saliva and urine of 96GS and SS animals [10], and in the blood of 96GG and GS animals [182]. However, interpretation of these results may be confounded by incompatibilities of the seed and substrate in their detection methods, i.e., RT-QuIC and 
Protein Misfolding Cyclic Amplification (PMCA), respectively. A study on mule deer PrP polymorphisms reported that 225SF mule deer were subclinical for longer periods of time but, nevertheless, had detectable $\mathrm{PrP}^{\mathrm{CWD}}$ in their lymph nodes, suggesting possibilities of longer shedding periods [111]. These studies are limited to small numbers of animals but, nevertheless, provide preliminary proof that PrP polymorphisms can indeed affect $\mathrm{PrP}^{\mathrm{CWD}}$ shedding and warrant further investigations with larger group sizes.

\section{Transmission Barriers and Zoonotic Potential of CWD}

With the emergence of CWD and its continuous spread, assessing the host range and transmission barriers to other species became a priority. A study by Bruce et al. (2000) demonstrated an inefficient transmission of $\mathrm{PrP}^{\mathrm{CWD}}$ isolates to non-transgenic laboratory mouse strains [183], suggesting a strong transmission barrier of CWD. Later, studies with hamsters and transgenic mice expressing hamster PrP showed the susceptibility of these species to CWD at variable attack rate via intracerebral route [184]. Interestingly, CWD was reported to be efficiently transmitted to transgenic mice overexpressing murine $\operatorname{PrP}$, while mouse-adapted $\operatorname{Pr} \mathrm{P}^{\mathrm{CWD}}$ showed lympho-tropism and biochemical and histological characteristics that resembled those from CWD-infected cervids [185]. Moreover, emergence of different $\mathrm{PrP} \mathrm{PWD}^{\mathrm{CWD}}$ strains, differing in disease incubation period and neuropathology, was observed when the mule deer PrPCWD isolate was serially passaged into Syrian golden hamster (SGH) and transgenic mice expressing SGH hamster PrP [184]. North American wild rodents, such as meadow voles, deer mice, and white-footed mice, were susceptible to CWD infection via the intracerebral route and supported prion adaptation upon subsequent passaging [186]. Interestingly, transmission of CWD to bank voles resulted in very efficient transmission with $100 \%$ attack rate and short incubation period [187]. Besides, ferrets showed susceptibility to CWD challenge and were useful in dissecting $\mathrm{PrP}^{\mathrm{CWD}}$ strains [188-190]. Additionally, CWD could transmit to cats, yet, with low attack rate and resulting in longer incubation periods. Attack rate increased, while incubation periods decreased, upon $\mathrm{PrP}^{\mathrm{CWD}}$ adaptation in second passage [191]. Indeed, the feline-adapted PrPCWD was able to transmit disease in cats following oral challenge which was not the case for cervid-derived $\operatorname{PrPCWD}$ [191]. Notably, histological analysis revealed that disease produced by feline-adapted $\mathrm{PrPCWD}$ in cats was distinct in terms of neuropathology when compared to that elicited by CWD and Feline Spongiform Encephalopathy (FSE), respectively [192]. A major challenge is the threat CWD poses to human health. CWD would have a significant impact on public health if it transmits directly to humans, or to potential intermediate hosts for transmission to humans, e.g., livestock [193-195]. When PrPCWD from WTD was inoculated either i.c. or orally into pigs, $\mathrm{PrPSc}^{\mathrm{Sc}}$ was detected in brain and lymphoid tissues even at 6 months post-inoculation by immunoassays and RT-QuIC, despite the absence of clinical disease [196]. Interestingly, the pig-adapted $\operatorname{PrP}^{\mathrm{CWD}}$ had distinct electrophoretic mobility when compared to pig-adapted $\operatorname{PrP}^{\mathrm{BSE}}$ and cervid $\operatorname{PrP}^{\mathrm{CWD}}$ [196]. Besides, the $\mathrm{PrP}^{\mathrm{CWD}}$-positive brain samples from some i.c. or orally $\mathrm{PrP}^{\mathrm{CWD}}$-inoculated pigs produced prion disease in transgenic mice expressing porcine PrP [196]. Although the study in pigs showed low CWD transmission, the data suggest that the presence of CWD infectivity in pigs by bioassays are enough to raise serious concerns regarding the role of livestock and wild boar as intermediate hosts, either at the clinical or sub-clinical disease stage, in the zoonotic transmission of CWD [196]. Such cross-species CWD transmission could be critical in areas where deer and these intermediary hosts share pastures. Perhaps reassuringly, CWD transmission studies to cattle suggested limited susceptibility upon intracerebral challenge that result in an incomplete attack rate and unique disease feature, distinct from BSE, with no spongiform changes in the brain [197-200]. Recently, a 10-year follow-up study demonstrated the failure of CWD transmission to cattle either when they were orally challenged with mule deer $\mathrm{PrP}^{\mathrm{CWD}}$ or co-housed with CWD-infected cervids and in $\mathrm{PrP}^{\mathrm{CWD}}$-contaminated environment, suggesting a high transmission barrier of cattle to CWD upon natural exposure [201]. CWD transmission was also not successful to transgenic mice expressing heterologous PrP from different species, including bovine, ovine 
and human, indicating a high interspecies transmission barrier for CWD [202,203]. Of note, difference between the primary structure of the host $\mathrm{PrP}$ and invading $\mathrm{PrPSc}$ play a major role in species barrier [41,204-206]. Yet, more investigation into the potential of interspecies transmission of CWD is required, considering the facts that various $\mathrm{PrP}^{\mathrm{CWD}}$ strains exist and that Prnp polymorphisms have an influence on strain generation, CWD pathogenesis and transmission $[92,120,146]$. Overall, the long incubation period, presence of different prion strains, effect of Prnp polymorphism, and atypical clinical presentation should be taken into consideration while assessing the threat posed by CWD.

The possibility of immediate transmission of CWD from cervids to humans has been a keen interest for prion researchers to address from the time when CWD was first detected. Moreover, the presence of $\mathrm{PrP}^{\mathrm{CWD}}$ in the skeletal muscles and antler velvet is alarming due to meat consumption and the use of antler velvet in traditional Asian medicines $[5,165]$. Surveillance data from CWD-endemic areas suggested no link between the CWD prevalence and incidence of prion disease, either typical or atypical/novel, in humans [207]. There were also no differences in terms of human CJD prevalence in CWD endemic vs. non-endemic areas in Colorado from 1979 to 2001 [208]. Although a retrospective study in the U.S. reported that some people who developed CJD were exposed to CWD in their past through diet [209], in follow-up studies for six years no prion disease was reported for those exposed to CWD via consumption of $\mathrm{PrPCWD}^{\mathrm{C}}$-infected deer meat [210]. Yet, the long incubation period of prion disease should not be underestimated during such follow-up studies. In an in vitro study using PMCA, PrPCWD could readily convert human $\mathrm{PrP}$ substrate into $\mathrm{PrP} \mathrm{P}^{\mathrm{Sc}}$, though only after prion strain adaptation gained through subsequent passaging of $\mathrm{PrP}^{\mathrm{CWD}}$ in PMCA or in transgenic mouse models [211]. Another study analyzed the efficiency of $\operatorname{PrPCWD}$ to convert human $\operatorname{PrP}$ from the human and transgenic mouse brains; it found that human PrP was converted by PrPCWD regardless of the polymorphism at codon 129 of human PrP, but M129 PrP was a more efficient substrate than V129 [36]. Interestingly, the migration and glycoform pattern of the proteinase K-resistant $\mathrm{PrPCWD}$-converted-human PrP was similar to that of MM1 sporadic CJD (sCJD) and distinct from vCJD [36]. Moreover, RT-QuIC assays revealed that both cervid $\mathrm{PrP}^{\mathrm{CWD}}$ and feline-adapted $\mathrm{PrP} \mathrm{P}^{\mathrm{CWD}}$ effectively seeded recombinant human PrP with seeding activity higher than $\operatorname{PrP}^{\mathrm{BSE}}$ but was lower than $\mathrm{SCJD}$ [40]. In contrast to those in vitro findings, $\mathrm{PrP}^{\mathrm{CWD}}$ inoculated i.c. into transgenic mice overexpressing human PrP showed no CWD transmission, suggesting a strong interspecies transmission barrier [202,203,212]. Recently, using RT-QuIC, PrP amyloid seeding activity was assessed in the brains of transgenic mice overexpressing human $\mathrm{PrP}$ after inoculating them with CWD prions from mule deer, WTD, and elk [213]. Although the mice failed to show any typical prion clinical disease, and $\mathrm{PrP}^{\mathrm{CWD}}$ accumulation and neuropathology were not detected in the brains, RT-QuIC analysis detected amyloid seeding activity in the brains of a few $\mathrm{PrP}^{\mathrm{CWD}}$-inoculated mice [213].

The zoonotic potential of CWD was further evaluated using non-human primates as an experimental model. Experimental CWD transmission was successfully achieved in squirrel monkeys by both intracranial and oral infection routes, but in contrast, not in cynomolgus macaques [214-216]. In a more recent transmission study of CWD to cynomolgus macaques performed by a Canadian-led consortium, CWD prions were able to transmit and cause clinical signs in some animals challenged i.c or orally, mimicking the natural transmission route $[195,217]$. These contradictory reports for CWD transmission to non-human primates indicate some zoonotic potential of CWD, especially keeping in mind of the emergence of novel natural CWD strains [32], the longer incubation periods that could be exerted by prions while transmitting to macaques [218], and the possibility of subclinical or atypical disease presentation. While solid evidence for CWD transmission to humans is lacking, the question whether CWD could cross the species barrier and transmit to humans is still a top priority and a serious public health concern. Another important question is how CWD would manifest in humans, whether it can be diagnosed with currently used assays, and whether it would further transmit among humans. 


\section{Conclusions}

CWD is considered the most contagious prion disease. It is spreading efficiently among wild and farmed cervids, resulting in increasing case numbers and an expansion in geographic distribution. Principally, all cervid species that are currently exposed to CWD are highly susceptible to infection and clinical disease, but species-specific polymorphisms in Prnp on one or both alleles result in single amino acid substitutions in the PrP and modulate pathogenesis. In most cases, the presence of only one mutated allele extends the incubation period of infected animals. It is tempting to speculate whether breeding schemes selecting for animals with a genetic background of lower CWD susceptibility could be introduced as a management strategy to curb the spread of CWD, a practice that was successfully applied to manage scrapie in sheep. However, it is important to keep in mind that there is no absolute resistance to infection, and animals carrying less susceptible genotypes still propagate infectious prions and might shed them for a longer period of time during extended incubation. Datasets from experimental infection schemes of cervids carrying less susceptible genotypes addressing shedding are critically important but very limited, mostly due to the low number of animals with non-wild type genotypes in those studies. Another caveat is the emergence of a growing variety of $\mathrm{PrPCWD}^{\mathrm{C}}$ strains. Initially, it appeared that strain diversity in CWD is limited to basically two strains. In recent years, however, more $\mathrm{PrP} \mathrm{P}^{\mathrm{CWD}}$ strains were isolated mostly from cervids expressing $\mathrm{PrP}$ with a polymorphism (e.g., $\mathrm{H} 95^{+}, 116 \mathrm{AG}, 132 \mathrm{~L}$ ), demonstrating another significant role of $\mathrm{PrP}^{\mathrm{C}}$ primary structure variations in CWD pathogenesis. The main concern with these findings is that strains can have distinct host ranges, and for some of them clinical disease was achieved in a mouse model previously considered resistant to various $\mathrm{PrP}^{\mathrm{CWD}}$ isolates. An expanded host range may not only cause increased transmission among cervids, but also transmission to sympatric species, livestock and humans. Recent evidence suggests some zoonotic potential of CWD, raising concerns as hunting, which is popular in North America and Scandinavia, and widespread consumption of venison exposes people to CWD.

It is clearly recognizable that cervid Prnp polymorphisms add an additional layer of complexity for management and risk assessment of CWD. Samples obtained for CWD surveillance can and should be utilized not only for CWD testing, but also for genotyping, strain typing, and transmission studies. Altogether, solving CWD-associated challenges calls for a One Health approach encompassing collaboration between molecular and wildlife biologists, social scientists, and regulators to eventually contain the spread and reduce the risks to ecosystem, animal, and human health.

Author Contributions: M.I.A., S.H., S.C.C., S.T., and S.G. wrote the paper; S.G. and M.I.A. designed the content; S.G. and H.M.S. provided comments and edits to the manuscript. All authors read and edited the final manuscript. All authors have read and agreed to the published version of the manuscript.

Funding: This research received no external funding.

Acknowledgments: We are grateful to the Alberta Prion Research Institute, Genome Canada, Genome Alberta and the University of Calgary for funding. S.G. is supported by the Canada Research Chairs program. M.I.A. acknowledges support through the Alberta Graduate Excellence Scholarship.

Conflicts of Interest: The authors declare no conflict of interest. The funders had no role in the design of the study; in the collection, analyses, or interpretation of data; in the writing of the manuscript, or in the decision to publish the results.

\section{References}

1. Gilch, S.; Chitoor, N.; Taguchi, Y.; Stuart, M.; Jewell, J.E.; Schätzl, H.M. Chronic Wasting Disease. In Topics in Current Chemistry; Springer International Publishing: Cham, Switzerland, 2011; Volume 305, pp. 51-77.

2. Prusiner, S.B. Prions. Proc. Natl. Acad. Sci. USA 1998, 95, 13363-13383. [CrossRef] [PubMed]

3. Mathiason, C.K.; Powers, J.G.; Dahmes, S.J.; Osborn, D.A.; Miller, K.V.; Warren, R.J.; Mason, G.L.; Hays, S.A.; Hayes-Klug, J.; Seelig, D.M.; et al. Infectious Prions in the Saliva and Blood of Deer with Chronic Wasting Disease. Science 2006, 314, 133-136. [CrossRef] 
4. Jewell, J.E.; Brown, J.; Kreeger, T.; Williams, E.S. Prion protein in cardiac muscle of elk (Cervus elaphus nelsoni) and white-tailed deer (Odocoileus virginianus) infected with chronic wasting disease. J. Gen. Virol. 2006, 87, 3443-3450. [CrossRef] [PubMed]

5. Angers, R.C.; Browning, S.R.; Seward, T.S.; Sigurdson, C.J.; Miller, M.W.; Hoover, E.A. Prions in Skeletal Muscles of Deer with Chronic Wasting Disease. Science 2006, 311, 1117. [CrossRef] [PubMed]

6. Safar, J.G.; Lessard, P.; Tamgüney, G.; Freyman, Y.; Deering, C.; Letessier, F.; de Armond, S.J.; Prusiner, S.B. Transmission and Detection of Prions in Feces. J. Infect. Dis. 2008, 198, 81-89. [CrossRef] [PubMed]

7. Tamgüney, G.; Miller, M.W.; Wolfe, L.L.; Sirochman, T.M.; Glidden, D.V.; Palmer, C.G.S.; Lemus, A.; de Armond, S.J.; Prusiner, S.B. Asymptomatic deer excrete infectious prions in faeces. Nat. Cell Biol. 2009, 461, 529-532. [CrossRef]

8. Haley, N.J.; Mathiason, C.K.; Carver, S.; Zabel, M.D.; Telling, G.C.; Hoover, E.A. Detection of Chronic Wasting Disease Prions in Salivary, Urinary, and Intestinal Tissues of Deer: Potential Mechanisms of Prion Shedding and Transmission. J. Virol. 2011, 85, 6309-6318. [CrossRef]

9. John, T.R.; Schätzl, H.M.; Gilch, S. Early detection of chronic wasting disease prions in urine of pre-symptomatic deer by real-time quaking-induced conversion assay. Prion 2013, 7, 253-258. [CrossRef]

10. Henderson, D.M.; Denkers, N.D.; Hoover, C.E.; Garbino, N.; Mathiason, C.K.; Hoover, E.A. Longitudinal Detection of Prion Shedding in Saliva and Urine by Chronic Wasting Disease-Infected Deer by Real-Time Quaking-Induced Conversion. J. Virol. 2015, 89, 9338-9347. [CrossRef] [PubMed]

11. Cheng, Y.C.; Hannaoui, S.; John, T.R.; Dudas, S.; Czub, S.; Gilch, S. Early and Non-Invasive Detection of Chronic Wasting Disease Prions in Elk Feces by Real-Time Quaking Induced Conversion. PLoS ONE 2016, 11, e0166187. [CrossRef]

12. Kramm, C.; Pritzkow, S.; Lyon, A.; Nichols, T.; Morales, R.; Soto, C. Detection of Prions in Blood of Cervids at the Asymptomatic Stage of Chronic Wasting Disease. Sci. Rep. 2017, 7, 1-8. [CrossRef] [PubMed]

13. Henderson, D.M.; Tennant, J.M.; Haley, N.J.; Denkers, N.D.; Mathiason, C.K.; Hoover, E.A. Detection of chronic wasting disease prion seeding activity in deer and elk feces by real-time quaking-induced conversion. J. Gen. Virol. 2017, 98, 1953-1962. [CrossRef] [PubMed]

14. Tennant, J.M.; Li, M.; Henderson, D.M.; Tyer, M.L.; Denkers, N.D.; Haley, N.J.; Mathiason, C.K.; Hoover, E.A. Shedding and stability of CWD prion seeding activity in cervid feces. PLoS ONE 2020, 15, e0227094. [CrossRef]

15. Johnson, C.J.; Phillips, K.E.; Schramm, P.T.; McKenzie, D.; Aiken, J.M.; Pedersen, J.A. Prions Adhere to Soil Minerals and Remain Infectious. PLoS Pathog. 2006, 2, e32. [CrossRef] [PubMed]

16. Johnson, C.J.; Pedersen, J.A.; Chappell, R.J.; McKenzie, D.; Aiken, J.M. Oral Transmissibility of Prion Disease Is Enhanced by Binding to Soil Particles. PLoS Pathog. 2007, 3, e93. [CrossRef]

17. Bartelt-Hunt, S.L.; Bartz, J.C. Behavior of Prions in the Environment: Implications for Prion Biology. PLoS Pathog. 2013, 9, e1003113. [CrossRef]

18. Pritzkow, S.; Morales, R.; Moda, F.; Khan, U.; Telling, G.C.; Hoover, E.; Soto, C. Grass Plants Bind, Retain, Uptake, and Transport Infectious Prions. Cell Rep. 2015, 11, 1168-1175. [CrossRef] [PubMed]

19. Kuznetsova, A.; McKenzie, D.; Cullingham, C.; Aiken, J.M. Long-Term Incubation PrPCWD with Soils Affects Prion Recovery but Not Infectivity. Pathogens 2020, 9, 311. [CrossRef]

20. Miller, M.W.; Williams, E.S.; Hobbs, N.T.; Wolfe, L.L. Environmental Sources of Prion Transmission in Mule Deer. Emerg. Infect. Dis. 2004, 10, 1003-1006. [CrossRef]

21. Yuan, Q.; Telling, G.; Bartelt-Hunt, S.L.; Bartz, J.C. Dehydration of Prions on Environmentally Relevant Surfaces Protects Them from Inactivation by Freezing and Thawing. J. Virol. 2018, 92. [CrossRef]

22. Mathiason, C.K.; Hays, S.A.; Powers, J.; Hayes-Klug, J.; Langenberg, J.; Dahmes, S.J.; Osborn, D.A.; Miller, K.V.; Warren, R.J.; Mason, G.L.; et al. Infectious Prions in Pre-Clinical Deer and Transmission of Chronic Wasting Disease Solely by Environmental Exposure. PLoS ONE 2009, 4, e5916. [CrossRef] [PubMed]

23. Georgsson, G.; Sigurdarson, S.; Brown, P. Infectious agent of sheep scrapie may persist in the environment for at least 16 years. J. Gen. Virol. 2006, 87, 3737-3740. [CrossRef]

24. Williams, E.S.; Young, S. Chronic Wasting Diease of Captive Mule Deer: A Spongifom Encephalopathy. J. Wildl. Dis. 1980, 16, 89-98. [CrossRef]

25. Williams, E.S.; Young, S. Spongiform Encephalopathy of Rpcky Mountain Elk. J. Wildl. Dis. 1982, 18, 465-471. [CrossRef] [PubMed]

26. Williams, E.S.; Miller, M.W. Chronic wasting disease in deer and elk in North America: -EN- -FR- -ES-. Rev. Sci. Tech. OIE 2002, 21, 305-316. [CrossRef] [PubMed]

27. Sohn, H.-J.; Kim, J.-H.; Choi, K.-S.; Nah, J.-J.; Joo, Y.-S.; Jean, Y.-H.; Ahn, S.-W.; Kim, O.-K.; Kim, D.-Y.; Balachandran, A. A Case of Chronic Wasting Disease in an Elk Imported to Korea from Canada. J. Veter. Med. Sci. 2002, 64, 855-858. [CrossRef] [PubMed]

28. Expanding Distribution of Chronic Wasting Disease. Available online: https://www.usgs.gov/centers/nwhc/science/expandingdistribution-chronic-wasting-disease?qt-science_center_objects=0\#qt-science_center_objects (accessed on 15 December 2020).

29. Kahn, S.; Dubé, C.; Bates, L.; Balachandran, A. Chronic wasting disease in Canada: Part 1. Can. Veter. J. 2004, 45, 397-404.

30. Vikøren, T.; Våge, J.; Madslien, K.I.; Røed, K.H.; Rolandsen, C.M.; Tran, L.; Hopp, P.; Veiberg, V.; Heum, M.; Moldal, T.; et al. First Detection of Chronic Wasting Disease in a Wild Red Deer (Cervus elaphus) in Europe. J. Wildl. Dis. 2019, 55, 970-972. [CrossRef]

31. Benestad, S.L.; Mitchell, G.; Simmons, M.; Ytrehus, B.; Vikøren, T. First case of chronic wasting disease in Europe in a Norwegian free-ranging reindeer. Veter. Res. 2016, 47, 1-7. [CrossRef] 
32. Pirisinu, L.; Tran, L.; Chiappini, B.; Vanni, I.; di Bari, M.A.; Vaccari, G.; Vikøren, T.; Madslien, K.I.; Våge, J.; Spraker, T.; et al. Novel Type of Chronic Wasting Disease Detected in Moose (Alces alces), Norway. Emerg. Infect. Dis. 2018, 24, 2210-2218. [CrossRef]

33. ProMED-Mail Chronic Wasting Disease, Cervid-FINLAND: First Case, Moose. ProMED-mail. 2018. Available online: https: // promedmail.org/promed-post/?id=5684473 (accessed on 15 December 2020).

34. ProMED-Mail Chronic Wasting Disease-Sweden: (Norrbotten) Moose, First Case. ProMED-mail. 2019. Available online: https:/ / promedmail.org/promed-post/?id=6390297 (accessed on 15 December 2020).

35. Mysterud, A.; Benestad, S.L.; Rolandsen, C.M.; Våge, J. Policy implications of an expanded chronic wasting disease universe. J. Appl. Ecol. 2020, 58, 281-285. [CrossRef]

36. Barria, M.A.; Balachandran, A.; Morita, M.; Kitamoto, T.; Barron, R.; Manson, J.; Knight, R.; Ironside, J.W.; Head, M.W. Molecular Barriers to Zoonotic Transmission of Prions. Emerg. Infect. Dis. 2014, 20, 88-97. [CrossRef] [PubMed]

37. Caughey, B. Prion protein conversions: Insight into mechanisms, TSE transmission barriers and strains. Br. Med. Bull. 2003, 66, 109-120. [CrossRef] [PubMed]

38. Torres, J.-M.; Espinosa, J.-C.; Aguilar-Calvo, P.; Herva, M.-E.; Relaño-Ginés, A.; Villa-Diaz, A.; Morales, M.; Parra, B.; Alamillo, E.; Brun, A.; et al. Elements Modulating the Prion Species Barrier and Its Passage Consequences. PLoS ONE 2014, 9, e89722. [CrossRef] [PubMed]

39. Raymon, G.J.; Bossers, A.; Raymond, L.D.; O’Rourke, K.I.; McHolland, L.E.; Bryant, P.K. Evidence of a molecular barrier limiting susceptibility of humans, cattle and sheep to chronic wasting disease. EMBO J. 2000, 19, 4425-4430. [CrossRef]

40. Davenport, K.A.; Henderson, D.M.; Bian, J.; Telling, G.C.; Mathiason, C.K.; Hoover, E.A. Insights into Chronic Wasting Disease and Bovine Spongiform Encephalopathy Species Barriers by Use of Real-Time Conversion. J. Virol. 2015, 89, 9524-9531. [CrossRef]

41. Bruce, M.; Chree, A.; McConnell, I.; Foster, J.; Pearson, G.; Fraser, H. Transmission of bovine spongiform encephalopathy and scrapie to mice: Strain variation and the species barrier. Philos. Trans. R. Soc. B Biol. Sci. 1994, 343, 405-411. [CrossRef]

42. Angers, R.; Christiansen, J.; Nalls, A.V.; Kang, H.-E.; Hunter, N.; Hoover, E.; Mathiason, C.K.; Sheetz, M.; Telling, G.C. Structural effects of PrP polymorphisms on intra- and interspecies prion transmission. Proc. Natl. Acad. Sci. USA 2014, 111, 11169-11174. [CrossRef]

43. Schätzl, H.M.; da Costa, M.; Taylor, L.; Cohen, F.E.; Prusiner, S.B. Prion Protein Gene Variation Among Primates. J. Mol. Biol. 1995, 245, 362-374. [CrossRef]

44. Lee, L.Y.-L.; Chen, R.P.-Y. Quantifying the Sequence-Dependent Species Barrier between Hamster and Mouse Prions. J. Am. Chem. Soc. 2007, 129, 1644-1652. [CrossRef]

45. Sharma, A.; Bruce, K.L.; Chen, B.; Gyoneva, S.; Behrens, S.H.; Bommarius, A.S.; Chernoff, Y.O. Contributions of the Prion Protein Sequence, Strain, and Environment to the Species Barrier. J. Biol. Chem. 2016, 291, 1277-1288. [CrossRef]

46. Hill, A.F.; Joiner, S.; Linehan, J.; Desbruslais, M.; Lantos, P.L.; Collinge, J. Species-barrier-independent prion replication in apparently resistant species. Proc. Natl. Acad. Sci. USA 2000, 97, 10248-10253. [CrossRef]

47. Scott, M.; Foster, D.; Mirenda, C.; Serban, D.; Coufal, F.; Wälchli, M.; Torchia, M.; Groth, D.; Carlson, G.; DeArmond, S.J.; et al. Transgenic mice expressing hamster prion protein produce species-specific scrapie infectivity and amyloid plaques. Cell 1989, 59, 847-857. [CrossRef]

48. Horiuchi, M.; Priola, S.A.; Chabry, J.; Caughey, B. Interactions between heterologous forms of prion protein: Binding, inhibition of conversion, and species barriers. Proc. Natl. Acad. Sci. USA 2000, 97, 5836-5841. [CrossRef]

49. Deleault, N.R.; Lucassen, R.W.; Supattapone, S. RNA molecules stimulate prion protein conversion. Nat. Cell Biol. 2003, 425, 717-720. [CrossRef]

50. Baron, G.S.; Caughey, B.; Starke, D.W.; Chock, P.B.; Mieyal, J.J. Effect of Glycosylphosphatidylinositol Anchor-dependent and -independent Prion Protein Association with Model Raft Membranes on Conversion to the Protease-resistant Isoform. J. Biol. Chem. 2003, 278, 14883-14892. [CrossRef]

51. Deleault, N.R.; Harris, B.T.; Rees, J.R.; Supattapone, S. Formation of native prions from minimal components in vitro. Proc. Natl. Acad. Sci. USA 2007, 104, 9741-9746. [CrossRef] [PubMed]

52. Wang, F.; Wang, X.; Yuan, C.-G.; Ma, J. Generating a Prion with Bacterially Expressed Recombinant Prion Protein. Science 2010, 327, 1132-1135. [CrossRef]

53. Ma, J. The Role of Cofactors in Prion Propagation and Infectivity. PLoS Pathog. 2012, 8, e1002589. [CrossRef] [PubMed]

54. Makarava, N.; Baskakov, I.V. The Evolution of Transmissible Prions: The Role of Deformed Templating. PLoS Pathog. 2013, 9, e1003759. [CrossRef] [PubMed]

55. Gonzalez-Montalban, N.; Lee, Y.J.; Makarava, N.; Savtchenko, R.; Baskakov, I.V. Changes in prion replication environment cause prion strain mutation. FASEB J. 2013, 27, 3702-3710. [CrossRef] [PubMed]

56. Katorcha, E.; Gonzalez-Montalban, N.; Makarava, N.; Kovacs, G.G.; Baskakov, I.V. Prion replication environment defines the fate of prion strain adaptation. PLoS Pathog. 2018, 14, e1007093. [CrossRef]

57. Collinge, J. Prion Strain Mutation and Selection. Science 2010, 328, 1111-1112. [CrossRef] [PubMed]

58. Barrio, T.; Filali, H.; Otero, A.; Sheleby-Elías, J.; Marín, B.; Vidal, E.; Béringue, V.; Torres, J.M.; Groschup, M.; Andréoletti, O.; et al. Mixtures of prion substrains in natural scrapie cases revealed by ovinised murine models. Sci. Rep. 2020, 10, 1-15. [CrossRef]

59. Tanaka, M.; Chien, P.; Naber, N.; Cooke, R.; Weissman, J.S. Conformational variations in an infectious protein determine prion strain differences. Nat. Cell Biol. 2004, 428, 323-328. [CrossRef] [PubMed] 
60. Tanaka, M.; Collins, S.R.; Toyama, B.H.; Weissman, J.S. The physical basis of how prion conformations determine strain phenotypes. Nature 2006, 442, 585-589. [CrossRef] [PubMed]

61. Makarava, N.; Savtchenko, R.; Lasch, P.; Beekes, M.; Baskakov, I.V. Preserving prion strain identity upon replication of prions in vitro using recombinant prion protein. Acta Neuropathol. Commun. 2018, 6, 92. [CrossRef]

62. Solforosi, L.; Milani, M.; Mancini, N.; Clementi, M.; Burioni, R. A closer look at prion strains. Prion 2013, 7, 99-108. [CrossRef]

63. Makarava, N.; Kovacs, G.G.; Savtchenko, R.; Alexeeva, I.; Budka, H.; Rohwer, R.G.; Baskakov, I.V. Stabilization of a Prion Strain of Synthetic Origin Requires Multiple Serial Passages. J. Biol. Chem. 2012, 287, 30205-30214. [CrossRef]

64. Morales, R.; Abid, K.; Soto, C. The prion strain phenomenon: Molecular basis and unprecedented features. Biochim. Biophys. Acta Mol. Basis Dis. 2007, 1772, 681-691. [CrossRef]

65. Bruce, M.E.; McConnell, I.; Fraser, H.; Dickinson, A.G. The disease characteristics of different strains of scrapie in Sinc congenic mouse lines: Implications for the nature of the agent and host control of pathogenesis. J. Gen. Virol. 1991, 72, 595-603. [CrossRef]

66. Bruce, M.E.; Dickinson, A.G. Biological Evidence that Scrapie Agent Has an Independent Genome. J. Gen. Virol. 1987, 68, 79-89. [CrossRef]

67. Kimberlin, R.H.; Walker, C.A. Characteristics of a Short Incubation Model of Scrapie in the Golden Hamster. J. Gen. Virol. 1977, 34, 295-304. [CrossRef] [PubMed]

68. Lasmézas, C.I.; Deslys, J.-P.; Demaimay, R.; Adjou, K.T.; Lamoury, F.; Dormont, D.; Robain, O.; Ironside, J.; Hauw, J.-J. BSE transmission to macaques. Nat. Cell Biol. 1996, 381, 743-744. [CrossRef]

69. Bruce, M.E.; Will, R.G.; Ironside, J.W.; McConnell, I.; Drummond, D.; Suttie, A. Transmissions to mice indicate that 'new variant' CJD is caused by the BSE agent. Nature 1997, 389, 498-501. [CrossRef] [PubMed]

70. Hill, A.F.; Desbruslais, M.; Joiner, S.; Sidle, K.C.L.; Gowland, I.; Collinge, J.; Doey, L.J.; Lantos, P. The same prion strain causes vCJD and BSE. Nat. Cell Biol. 1997, 389, 448-450. [CrossRef] [PubMed]

71. Bencsik, A.; Debeer, S.; Petit, T.; Baron, T. Possible Case of Maternal Transmission of Feline Spongiform Encephalopathy in a Captive Cheetah. PLoS ONE 2009, 4, e6929. [CrossRef]

72. Zanusso, G.; Nardelli, E.; Rosati, A.; Fabrizi, G.; Ferrari, S.; Carteri, A.; de Simone, F.; Rizzuto, N.; Monaco, S. Simultaneous occurrence of spongiform encephalopathy in a man and his cat in Italy. Lancet 1998, 352, 1116-1117. [CrossRef]

73. Sigurdson, C.J.; Miller, M.W. Other animal prion diseases. Br. Med. Bull. 2003, 66, 199-212. [CrossRef]

74. Kirkwood, J.K.; Cunningham, A.A.; Wells, G.A.; Wilesmith, J.W.; Barnett, J.E. Spongiform encephalopathy in a herd of greater kudu (Tragelaphus strepsiceros): Epidemiological observations. Veter. Rec. 1993, 133, 360-364. [CrossRef]

75. Kirkwood, J.K.; Cunningham, A.A. Epidemiological observations on spongiform encephalopathies in captive wild animals in the British Isles. Veter. Rec. 1994, 135, 296-303. [CrossRef]

76. Imran, M.; Mahmood, S. An overview of animal prion diseases. Virol. J. 2011, 8, 493. [CrossRef] [PubMed]

77. Baron, T.; Belli, P.; Madec, J.Y.; Moutou, F.; Vitaud, C.; Savey, M. Spongiform encephalopathy in an imported cheetah in France. Veter. Rec. 1997, 141, 270-271. [CrossRef]

78. Li, J.; Browning, S.; Mahal, S.P.; Oelschlegel, A.M.; Weissmann, C. Darwinian Evolution of Prions in Cell Culture. Science 2009, 327, 869-872. [CrossRef] [PubMed]

79. Bartz, J.C.; Bessen, R.A.; McKenzie, D.; Marsh, R.F.; Aiken, J.M. Adaptation and Selection of Prion Protein Strain Conformations following Interspecies Transmission of Transmissible Mink Encephalopathy. J. Virol. 2000, 74, 5542-5547. [CrossRef] [PubMed]

80. Chien, P.; de Pace, A.H.; Collins, S.R.; Weissman, J.S. Generation of prion transmission barriers by mutational control of amyloid conformations. Nat. Cell Biol. 2003, 424, 948-951. [CrossRef] [PubMed]

81. Peretz, D.; Williamson, R.; Legname, G.; Matsunaga, Y.; Vergara, J.; Burton, D.R.; de Armond, S.J.; Prusiner, S.B.; Scott, M.R. A Change in the Conformation of Prions Accompanies the Emergence of a New Prion Strain. Neuron 2002, 34, 921-932. [CrossRef]

82. Igel-Egalon, A.; Laferrière, F.; Tixador, P.; Moudjou, M.; Herzog, L.; Reine, F. Crossing Species Barriers Relies on Structurally Distinct Prion Assemblies and Their Complementation. Mol. Neurobiol. 2020, 57, 2572-2587. [CrossRef]

83. Le Dur, A.; Laï, T.L.; Stinnakre, M.-G.; Laisné, A.; Chenais, N.; Rakotobe, S.; Passet, B.; Reine, F.; Soulier, S.; Herzog, L.; et al. Divergent prion strain evolution driven by PrPC expression level in transgenic mice. Nat. Commun. 2017, 8, 14170. [CrossRef]

84. Sigurdson, C.J.; Nilsson, K.P.R.; Hornemann, S.; Heikenwalder, M.; Manco, G.; Schwarz, P.; Ott, D.; Rülicke, T.; Liberski, P.P.; Julius, C.; et al. De novo generation of a transmissible spongiform encephalopathy by mouse transgenesis. Proc. Natl. Acad. Sci. USA 2008, 106, 304-309. [CrossRef]

85. Sigurdson, C.J.; Nilsson, K.P.R.; Hornemann, S.; Manco, G.; Fernández-Borges, N.; Schwarz, P.; Castilla, J.; Wüthrich, K.; Aguzzi, A. A molecular switch controls interspecies prion disease transmission in mice. J. Clin. Investig. 2010, 120, 2590-2599. [CrossRef] [PubMed]

86. Sigurdson, C.J.; Joshi-Barr, S.; Bett, C.; Winson, O.; Manco, G.; Schwarz, P. Spongiform Encephalopathy in Transgenic Mice Expressing a Point Mutation in the $\beta 2-\alpha 2$ Loop of the Prion Protein. J. Neurosci. 2011, 31, 13840-13847. [CrossRef]

87. Kurt, T.D.; Bett, C.; Fernández-Borges, N.; Joshi-Barr, S.; Hornemann, S.; Rülicke, T. Prion Transmission Prevented by Modifying the $\beta 2-\alpha 2$ Loop Structure of Host PrPC. J. Neurosci. 2014, 34, 1022-1027. [CrossRef]

88. Gossert, A.D.; Bonjour, S.; Lysek, D.A.; Fiorito, F.; Wüthrich, K. Prion protein NMR structures of elk and of mouse/elk hybrids. Proc. Natl. Acad. Sci. USA 2005, 102, 646-650. [CrossRef]

89. Harrathi, C.; Fernández-Borges, N.; Eraña, H.; Elezgarai, S.R.; Venegas, V.; Charco, J.M.; Castilla, J. Insights into the Bidirectional Properties of the Sheep-Deer Prion Transmission Barrier. Mol. Neurobiol. 2018, 56, 5287-5303. [CrossRef] [PubMed] 
90. Soto, C. Constraining the loop, releasing prion infectivity. Proc. Natl. Acad. Sci. USA 2008, 106, 10-11. [CrossRef] [PubMed]

91. Kyle, L.M.; John, T.R.; Schätzl, H.M.; Lewis, R.V. Introducing a Rigid Loop Structure from Deer into Mouse Prion Protein Increases Its Propensity for Misfolding In Vitro. PLoS ONE 2013, 8, e66715. [CrossRef]

92. Hannaoui, S.; Amidian, S.; Cheng, Y.C.; Velásquez, C.D.; Dorosh, L.; Law, S.; Telling, G.; Stepanova, M.; McKenzie, D.; Wille, H.; et al. Destabilizing polymorphism in cervid prion protein hydrophobic core determines prion conformation and conversion efficiency. PLoS Pathog. 2017, 13, e1006553. [CrossRef]

93. Velásquez, C.D.; Kim, C.; Herbst, A.; Daude, N.; Garza, M.C.; Wille, H.; Aiken, J.M.; McKenzie, D. Deer Prion Proteins Modulate the Emergence and Adaptation of Chronic Wasting Disease Strains. J. Virol. 2015, 89, 12362-12373. [CrossRef]

94. Hagenaars, T.J.; Melchior, M.B.; Windig, J.J.; Bossers, A.; Davidse, A.; van Zijderveld, F.G. Modelling of strategies for genetic control of scrapie in sheep: The importance of population structure. PLoS ONE 2018, 13, e0195009. [CrossRef] [PubMed]

95. Sacchi, P.; Rasero, R.; Ru, G.; Aiassa, E.; Colussi, S.; Ingravalle, F.; Peletto, S.; Perrotta, M.G.; Sartore, S.; Soglia, D.; et al. Predicting the impact of selection for scrapie resistance on PRNP genotype frequencies in goats. Veter. Res. 2018, 49, 1-13. [CrossRef]

96. Ricci, A.; Allende, A.; Bolton, D.; Chemaly, M.; Davies, R.; Escámez, P.S.F.; Gironés, R.; Herman, L.; Koutsoumanis, K.; Lindqvist, R.; et al. Genetic resistance to transmissible spongiform encephalopathies (TSE) in goats. EFSA J. 2017, 15, e04962. [CrossRef]

97. Nodelijk, G.; van Roermund, H.J.; van Keulen, L.J.; Engel, B.; Vellema, P.; Hagenaars, T.J. Breeding with resistant rams leads to rapid control of classical scrapie in affected sheep flocks. Veter. Res. 2011, 42, 5. [CrossRef]

98. Wik, L.; Mikko, S.; Klingeborn, M.; Stéen, M.; Simonsson, M.; Linné, T. Polymorphisms and variants in the prion protein sequence of European moose (Alces alces), reindeer (Rangifer tarandus), roe deer (Capreolus capreolus) and fallow deer (Dama dama) in Scandinavia. Prion 2012, 6, 256-260. [CrossRef]

99. Robinson, S.J.; Samuel, M.D.; O'Rourke, K.I.; Johnson, C.J. The role of genetics in chronic wasting disease of North American cervids. Prion 2012, 6, 153-162. [CrossRef]

100. Sigurdson, C.J. A prion disease of cervids: Chronic wasting disease. Veter. Res. 2008, 39, 1-12. [CrossRef]

101. Haley, N.J.; Merrett, K.; Stein, A.B.; Simpson, D.; Carlson, A.; Mitchell, G.; Staskevicius, A.; Nichols, T.; Lehmkuhl, A.D.; Thomsen, B.V. Estimating relative CWD susceptibility and disease progression in farmed white-tailed deer with rare PRNP alleles. PLoS ONE 2019, 14, e0224342. [CrossRef] [PubMed]

102. Johnson, C.; Johnson, J.; Clayton, M.; McKenzie, D.; Aiken, J. Prion Protein Gene Heterogeneity in Free-Ranging White-Taikde Deer Within the Chronic Wasting Disease Affected Region of Wisconsin. J. Wildl. Dis. 2003, 39, 576-581. [CrossRef] [PubMed]

103. Johnson, C.; Johnson, J.; Vanderloo, J.P.; Keane, D.; Aiken, J.M.; McKenzie, D. Prion protein polymorphisms in white-tailed deer influence susceptibility to chronic wasting disease. J. Gen. Virol. 2006, 87, 2109-2114. [CrossRef] [PubMed]

104. Johnson, C.J.; Herbst, A.; Duque-Velasquez, C.; Vanderloo, J.P.; Bochsler, P.; Chappell, R.; McKenzie, D. Prion Protein Polymorphisms Affect Chronic Wasting Disease Progression. PLoS ONE 2011, 6, e17450. [CrossRef]

105. Otero, A.; Velásquez, C.D.; Johnson, C.; Herbst, A.; Bolea, R.; Badiola, J.J.; Aiken, J.; McKenzie, D. Prion protein polymorphisms associated with reduced CWD susceptibility limit peripheral PrPCWD deposition in orally infected white-tailed deer. BMC Veter. Res. 2019, 15, 1-14. [CrossRef] [PubMed]

106. O’Rourke, K.I.; Spraker, T.R.; Hamburg, L.K.; Besser, T.E.; Brayton, K.A.; Knowles, D.P.; Mercier, S.; Verhaagh, S.; Goudsmit, J.; Lemckert, A.; et al. Polymorphisms in the prion precursor functional gene but not the pseudogene are associated with susceptibility to chronic wasting disease in white-tailed deer. J. Gen. Virol. 2004, 85, 1339-1346. [CrossRef]

107. Haley, N.J.; Siepker, C.; Walter, W.D.; Thomsen, B.V.; Greenlee, J.J.; Lehmkuhl, A.D.; Richt, J.A. Antemortem Detection of Chronic Wasting Disease Prions in Nasal Brush Collections and Rectal Biopsy Specimens from White-Tailed Deer by Real-Time Quaking-Induced Conversion. J. Clin. Microbiol. 2016, 54, 1108-1116. [CrossRef] [PubMed]

108. Keane, D.P.; Barr, D.J.; Bochsler, P.N.; Hall, S.M.; Gidlewski, T.; O’Rourke, K.I.; Spraker, T.R.; Samuel, M.D. Chronic Wasting Disease in a Wisconsin White-Tailed Deer Farm. J. Veter. Diagn. Investig. 2008, 20, 698-703. [CrossRef] [PubMed]

109. Wilson, G.A.; Nakada, S.M.; Bollinger, T.K.; Pybus, M.J.; Merrill, E.H.; Coltman, D.W. Polymorphisms at the PRNP Gene Influence Susceptibility to Chronic Wasting Disease in Two Species of Deer (Odocoileus Spp.) in Western Canada. J. Toxicol. Environ. Health Part A 2009, 72, 1025-1029. [CrossRef] [PubMed]

110. Jewell, J.E.; Conner, M.M.; Wolfe, L.L.; Miller, M.W.; Williams, E.S. Low frequency of PrP genotype 225SF among free-ranging mule deer (Odocoileus hemionus) with chronic wasting disease. J. Gen. Virol. 2005, 86, 2127-2134. [CrossRef]

111. Fox, K.A.; Jewell, J.E.; Williams, E.S.; Miller, M.W. Patterns of PrPCWD accumulation during the course of chronic wasting disease infection in orally inoculated mule deer (Odocoileus hemionus). J. Gen. Virol. 2006, 87, 3451-3461. [CrossRef]

112. Schätzl, H.M.; Wopfner, F.; Gilch, S.; von Brunn, A.; Jäger, G. Is codon 129 of prion protein polymorphic in human beings but not in animals? Lancet 1997, 349, 1603-1604. [CrossRef]

113. O’Rourke, K.I.; Besser, T.E.; Miller, M.W.; Cline, T.F.; Spraker, T.R.; Jenny, A.L.; Wild, M.A.; Zebarth, G.L.; Williams, E.S. PrP genotypes of captive and free-ranging Rocky Mountain elk (Cervus elaphus nelsoni) with chronic wasting disease. J. Gen. Virol. 1999, 80. [CrossRef]

114. Hamir, A.N.; Gidlewski, T.; Spraker, T.R.; Miller, J.M.; Creekmore, L.; Crocheck, M.; Cline, T.; O’Rourke, K.I. Preliminary Observations of Genetic Susceptibility of elk (Cervus Elaphus Nelsoni) to Chronic Wasting Disease by Experimental Oral Inoculation. J. Veter. Diagn. Investig. 2006, 18, 110-114. [CrossRef]

115. O'Rourke, K.I.; Spraker, T.R.; Zhuang, D.; Greenlee, J.J.; Gidlewski, T.E.; Hamir, A.N. Elk with a long incubation prion disease phenotype have a unique PrPd profile. NeuroReport 2007, 18, 1935-1938. [CrossRef] [PubMed] 
116. Perucchini, M.; Griffin, K.; Miller, M.W.; Goldmann, W. PrP genotypes of free-ranging wapiti (Cervus elaphus nelsoni) with chronic wasting disease. J. Gen. Virol. 2008, 89, 1324-1328. [CrossRef] [PubMed]

117. Monello, R.J.; Galloway, N.L.; Powers, J.G.; Madsen-Bouterse, S.A.; Edwards, W.H.; Wood, M.E.; O’Rourke, K.I.; Wild, M.A. Pathogen-mediated selection in free-ranging elk populations infected by chronic wasting disease. Proc. Natl. Acad. Sci. USA 2017, 114, 12208-12212. [CrossRef] [PubMed]

118. Moore, S.J.; Vrentas, C.E.; Hwang, S.; Greenlee, M.H.W.; Nicholson, E.M.; Greenlee, J.J. Pathologic and biochemical characterization of PrPSc from elk with PRNP polymorphisms at codon 132 after experimental infection with the chronic wasting disease agent. BMC Veter. Res. 2018, 14,1-11. [CrossRef] [PubMed]

119. Cervenáková, L.; Rohwer, R.; Williams, S.; Brown, P.; Gajdusek, D.C. High sequence homology of the PrP gene in mule deer and Rocky Mountain elk. Lancet 1997, 350, 219-220. [CrossRef]

120. Bian, J.; Christiansen, J.R.; Moreno, J.A.; Kane, S.J.; Khaychuk, V.; Gallegos, J. Primary structural differences at residue 226 of deer and elk PrP dictate selection of distinct CWD prion strains in gene-targeted mice. Proc. Natl. Acad. Sci. USA 2019, $2019,03947$. [CrossRef]

121. Robinson, A.L.; Williamson, H.; Güere, M.E.; Tharaldsen, H.; Baker, K.; Smith, S.L.; Pérez-Espona, S.; Krojerová-Prokešová, J.; Pemberton, J.M.; Goldmann, W.; et al. Variation in the prion protein gene (PRNP) sequence of wild deer in Great Britain and mainland Europe. Veter. Res. 2019, 50,1-10. [CrossRef]

122. Hamir, A.; Kunkle, R.; Nicholson, E.; Miller, J.; Hall, S.; Schoenenbruecher, H.; Brunelle, B.; Richt, J. Preliminary Observations on the Experimental Transmission of Chronic Wasting Disease (CWD) from Elk and White-Tailed Deer to Fallow Deer. J. Comp. Pathol. 2008, 138, 121-130. [CrossRef]

123. Rhyan, J.C.; Miller, M.W.; Spraker, T.R.; Mccollum, M.; Nol, P.; Wolfe, L.L.; Davis, T.R.; Creekmore, L.; O’Rourke, K.I. Failure of Fallow Deer (Dama dama) to Develop Chronic Wasting Disease When Exposed to a Contaminated Environment and Infected Mule Deer (Odocoileus hemionus). J. Wildl. Dis. 2011, 47, 739-744. [CrossRef]

124. Hamir, A.N.; Greenlee, J.J.; Nicholson, E.M.; Kunkle, R.A.; Richt, J.A.; Miller, J.M.; Hall, M. Experimental transmission of chronic wasting disease (CWD) from elk and white-tailed deer to fallow deer by intracerebral route: Final report. Can. J. Veter. Res. 2011, 75, 152-156.

125. Roh, I.S.; Kim, H.J.; Kim, H.J.; Suh, T.Y.; Han, J.H.; Kang, H.E.; Sohn, H.J. Polymorphisms in the Prion Protein Gene, Associated with Chronic Wasting Disease, in the Korean Water Deer (Hydropotes inermis argyropus). J. Veter. Sci. Technol. 2018, 9, 1-4. [CrossRef]

126. Jeong, H.-J.; Lee, J.-B.; Park, S.-Y.; Chang-Seon, S.; Kim, B.-S.; Rho, J.-R. Single-nucleotide polymorphisms in prion protein gene of the Korean subspecies of Chinese water deer (Hydropotes inermis argyropus). Korean J. Vet. Res. 2009, 49, 59-62.

127. Cullingham, C.I.; Peery, R.M.; Dao, A.; McKenzie, D.I.; Coltman, D.W. Predicting the spread-risk potential of chronic wasting disease to sympatric ungulate species. Prion 2020, 14, 56-66. [CrossRef] [PubMed]

128. Kreeger, T.J.; Montgomery, D.L.; Jewell, J.E.; Schultz, W.; Williams, E.S. Oral Transmission of Chronic Wasting Disease in Captive Shira's Moose. J. Wildl. Dis. 2006, 42, 640-645. [CrossRef]

129. Huson, H.J.; Happ, G.M. Polymorphisms of the prion protein gene (PRNP) in Alaskan moose (Alces alces gigas). Anim. Genet. 2006, 37, 425-426. [CrossRef]

130. Happ, G.M.; Huson, H.J.; Beckmen, K.B.; Kennedy, L.J. Prion Protein Genes in Caribou from Alaska. J. Wildl. Dis. 2007, 43, 224-228. [CrossRef]

131. Mitchell, G.B.; Sigurdson, C.J.; O’Rourke, K.I.; Algire, J.; Harrington, N.P.; Walther, I.; Spraker, T.R.; Balachandran, A. Experimental Oral Transmission of Chronic Wasting Disease to Reindeer (Rangifer tarandus tarandus). PLoS ONE 2012, 7, e39055. [CrossRef] [PubMed]

132. Cheng, Y.C.; Musiani, M.; Cavedon, M.; Gilch, S. High prevalence of prion protein genotype associated with resistance to chronic wasting disease in one Alberta woodland caribou population. Prion 2017, 11, 136-142. [CrossRef] [PubMed]

133. Arifin, M.I.; Staskevicius, A.; Shim, S.Y.; Huang, Y.; Fenton, H.; McLoughlin, P.D.; Mitchell, G.; Cullingham, C.I.; Gilch, S. Largescale prion protein genotyping in Canadian caribou populations and potential impact on chronic wasting disease susceptibility. Mol. Ecol. 2020, 29, 3830-3840. [CrossRef] [PubMed]

134. Moore, S.J.; Kunkle, R.; Greenlee, M.H.W.; Nicholson, E.; Richt, J.; Hamir, A.; Waters, W.R.; Greenlee, J. Horizontal Transmission of Chronic Wasting Disease in Reindeer. Emerg. Infect. Dis. 2016, 22, 2142-2145. [CrossRef]

135. Güere, M.E.; Våge, J.; Tharaldsen, H.; Benestad, S.L.; Vikøren, T.; Madslien, K.; Hopp, P.; Rolandsen, C.M.; Røed, K.H.; Tranulis, M.A. Chronic wasting disease associated with prion protein gene (PRNP) variation in Norwegian wild reindeer (Rangifer tarandus). Prion 2020, 14, 1-10. [CrossRef] [PubMed]

136. Vorberg, I.; Chan, K.; Priola, S.A. Deletion of $\beta$-Strand and $\alpha$-Helix Secondary Structure in Normal Prion Protein Inhibits Formation of Its Protease-Resistant Isoform. J. Virol. 2001, 75, 10024-10032. [CrossRef]

137. Collinge, J.; Palmer, M.; Dryden, A. Genetic predisposition to iatrogenic Creutzfeldt-Jakob disease. Lancet 1991, $337,1441-1442$. [CrossRef]

138. Palmer, M.S.; Dryden, A.J.; Hughes, J.T.; Collinge, J. Homozygous prion protein genotype predisposes to sporadic CreutzfeldtJakob disease. Nat. Cell Biol. 1991, 352, 340-342. [CrossRef]

139. O'Rourke, K.I.; Baszler, T.V.; Miller, J.M.; Spraker, T.R.; Sadler-Riggleman, I.; Knowles, D.P. Monoclonal Antibody F89/160.1.5 Defines a Conserved Epitope on the Ruminant Prion Protein. J. Clin. Microbiol. 1998, 36, 1750-1755. [CrossRef] 
140. Moore, J.; Tatum, T.; Hwang, S.; Vrentas, C.; Greenlee, M.H.W.; Kong, Q.; Nicholson, E.; Greenlee, J. Novel Strain of the Chronic Wasting Disease Agent Isolated from Experimentally Inoculated Elk with LL132 Prion Protein. Sci. Rep. 2020, 10, 1-13. [CrossRef]

141. Brayton, K.A.; O’Rourke, K.I.; Lyda, A.K.; Miller, M.W.; Knowles, D.P. A processed pseudogene contributes to apparent mule deer prion gene heterogeneity. Gene 2004, 326, 167-173. [CrossRef] [PubMed]

142. Wolfe, L.L.; Fox, K.A.; Miller, M.W. “Atypical” Chronic Wasting Disease in PRNP Genotype 225FF Mule Deer. J. Wildl. Dis. 2014, 50, 660-665. [CrossRef] [PubMed]

143. Heaton, M.P.; Leymaster, K.A.; Freking, B.A.; Hawk, D.A.; Smith, T.P.L.; Keele, J.W.; Snelling, W.M.; Fox, J.M.; Chitko-McKown, C.G.; Laegreid, W.W. Prion gene sequence variation within diverse groups of U.S. sheep, beef cattle, and deer. Mamm. Genome 2003, 14, 765-777. [CrossRef]

144. Robinson, S.J.; Samuel, M.D.; Johnson, C.J.; Adams, M.; McKenzie, D.I. Emerging prion disease drives host selection in a wildlife population. Ecol. Appl. 2012, 22, 1050-1059. [CrossRef]

145. Kelly, A.C.; Mateus-Pinilla, N.E.; Diffendorfer, J.; Jewell, E.; Ruiz, M.O.; Killefer, J.; Shelton, P.; Beissel, T.; Novakofski, J. Prion sequence polymorphisms and chronic wasting disease resistance in Illinois white-tailed deer (Odocoileus virginianus). Prion 2008, 2, 28-36. [CrossRef]

146. Herbst, A.; Velásquez, C.D.; Triscott, E.; Aiken, J.M.; McKenzie, D. Chronic Wasting Disease Prion Strain Emergence and Host Range Expansion. Emerg. Infect. Dis. 2017, 23, 1598-1600. [CrossRef]

147. Duque-Velásquez, C.; Kim, C.; Haldiman, T.; Kim, C.; Herbst, A.; Aiken, J.M. Chronic wasting disease (CWD) prion strains evolve via adaptive diversification of conformers in hosts expressing prion protein polymorphisms. J. Biol. Chem. 2020, 15, 4985-5001. [CrossRef] [PubMed]

148. Meade-White, K.; Race, B.; Trifilo, M.; Bossers, A.; Favara, C.; Lacasse, R.; Miller, M.; Williams, E.; Oldstone, M.; Race, R.; et al. Resistance to Chronic Wasting Disease in Transgenic Mice Expressing a Naturally Occurring Allelic Variant of Deer Prion Protein. J. Virol. 2007, 81, 4533-4539. [CrossRef]

149. Race, B.; Meade-White, K.; Miller, M.W.; Fox, K.A.; Chesebro, B. In Vivo Comparison of Chronic Wasting Disease Infectivity from Deer with Variation at Prion Protein Residue 96. J. Virol. 2011, 85, 9235-9238. [CrossRef]

150. Chabry, J.; Caughey, B.; Chesebro, B. Specific Inhibition of in Vitro Formation of Protease-resistant Prion Protein by Synthetic Peptides. J. Biol. Chem. 1998, 273, 13203-13207. [CrossRef]

151. Hölscher, C.; Delius, H.; Bürkle, A. Overexpression of Nonconvertible PrPc $\Delta 114-121$ in Scrapie-Infected Mouse Neuroblastoma Cells Leads to trans-Dominant Inhibition of Wild-Type PrPSc Accumulation. J. Virol. 1998, 72, 1153-1159. [CrossRef] [PubMed]

152. Wopfner, F.; Weidenhöfer, G.; Schneider, R.; von Brunn, A.; Gilch, S.; Schwarz, T.F. Analysis of 27 mammalian and 9 avian PrPs reveals high conservation of flexible regions of the prion protein 11Edited by A. R. Fersht. J. Mol. Biol. 1999, 289, 1163-1178. [CrossRef]

153. Wang, F.; Yin, S.; Wang, X.; Zha, L.; Sy, M.-S.; Ma, J. Role of the Highly Conserved Middle Region of PrP in PrP-Lipid Interaction. Biochemistry 2010, 49, 8169-8176. [CrossRef]

154. Hegde, R.S.; Mastrianni, J.A.; Scott, M.R.; DeFea, K.A.; Tremblay, P.; Torchia, M.; DeArmond, S.J.; Prusiner, S.B.; Lingappa, V.R. A Transmembrane Form of the Prion Protein in Neurodegenerative Disease. Science 1998, 279, 827-834. [CrossRef] [PubMed]

155. Kurt, T.D.; Telling, G.C.; Zabel, M.D.; Hoover, E.A. Trans-species amplification of PrPCWD and correlation with rigid loop 170 N. Virology 2009, 387, 235-243. [CrossRef]

156. Kurt, T.D.; Jiang, L.; Fernández-Borges, N.; Bett, C.; Liu, J.; Yang, T. Human prion protein sequence elements impede cross-species chronic wasting disease transmission. J. Clin. Investig. 2015, 125, 1485-1496. [CrossRef] [PubMed]

157. Pérez, D.R.; Damberger, F.F.; Wüthrich, K. Horse Prion Protein NMR Structure and Comparisons with Related Variants of the Mouse Prion Protein. J. Mol. Biol. 2010, 400, 121-128. [CrossRef] [PubMed]

158. Atarashi, R.; Satoh, K.; Sano, K.; Fuse, T.; Yamaguchi, N.; Ishibashi, D.; Matsubara, T.; Nakagaki, T.; Yamanaka, H.; Shirabe, S.; et al. Ultrasensitive human prion detection in cerebrospinal fluid by real-time quaking-induced conversion. Nat. Med. 2011, 17, 175-178. [CrossRef]

159. Haley, N.J.; Rielinger, R.; Davenport, K.A.; O’Rourke, K.; Mitchell, G.; Richt, J.A. Estimating chronic wasting disease susceptibility in cervids using real-time quaking-induced conversion. J. Gen. Virol. 2017, 98, 2882-2892. [CrossRef] [PubMed]

160. Scialò, C.; de Cecco, E.; Manganotti, P.; Legname, G. PRION 2019 emerging concepts. Prion 2019, 13 (Suppl. 1), 1-141.

161. Pattison, I.; Millson, G. Scrapie Produced Experimentally in Goats with Special Reference to the Clinical Syndrome. J. Comp. Pathol. Ther. 1961, 71, 101-110. [CrossRef]

162. Aguzzi, A.; Heikenwalder, M.; Polymenidou, M. Insights into prion strains and neurotoxicity. Nat. Rev. Mol. Cell Biol. 2007, 8, 552-561. [CrossRef]

163. Angers, R.C.; Kang, H.-E.; Napier, D.; Browning, S.; Seward, T.; Mathiason, C.; Balachandran, A.; McKenzie, D.; Castilla, J.; Soto, C.; et al. Prion Strain Mutation Determined by Prion Protein Conformational Compatibility and Primary Structure. Science 2010, 328, 1154-1158. [CrossRef]

164. Collinge, J.; Clarke, A.R. A General Model of Prion Strains and Their Pathogenicity. Science 2007, 318, 930-936. [CrossRef] [PubMed]

165. Angers, R.C.; Seward, T.S.; Napier, D.; Green, M.; Hoover, E.; Spraker, T.; O’Rourke, K.; Balachandran, A.; Telling, G.C. Chronic Wasting Disease Prions in Elk Antler Velvet. Emerg. Infect. Dis. 2009, 15, 696-703. [CrossRef] 
166. Safar, J.; Wille, H.; Itri, V.; Groth, D.; Serban, H.; Torchia, M.; Cohen, F.E.; Prusiner, S.B. Eight prion strains have PrP Sc molecules with different conformations. Nat. Med. 1998, 4, 1157-1165. [CrossRef]

167. Bian, J.; Kang, H.-E.; Telling, G.C. Quinacrine promotes replication and conformational mutation of chronic wasting disease prions. Proc. Natl. Acad. Sci. USA 2014, 111, 6028-6033. [CrossRef] [PubMed]

168. Browning, S.R.; Mason, G.L.; Seward, T.; Green, M.; Eliason, G.A.J.; Mathiason, C. Transmission of Prions from Mule Deer and Elk with Chronic Wasting Disease to Transgenic Mice Expressing Cervid PrP. J. Virol. 2004, 78, 13345-13350. [CrossRef]

169. Hoover, C.E.; Davenport, K.A.; Henderson, D.M.; Denkers, N.D.; Mathiason, C.K.; Soto, C.; Zabel, M.D.; Hoover, E.A. Pathways of Prion Spread during Early Chronic Wasting Disease in Deer. J. Virol. 2017, 91, e00077-17. [CrossRef] [PubMed]

170. Shearin, H.; Bessen, R.A. Axonal and Transynaptic Spread of Prions. J. Virol. 2014, 88, 8640-8655. [CrossRef] [PubMed]

171. Mathiason, C.K.; Hayes-Klug, J.; Hays, S.A.; Powers, J.; Osborn, D.A.; Dahmes, S.J.; Miller, K.V.; Warren, R.J.; Mason, G.L.; Telling, G.C.; et al. B Cells and Platelets Harbor Prion Infectivity in the Blood of Deer Infected with Chronic Wasting Disease. J. Virol. 2010, 84, 5097-5107. [CrossRef]

172. Hamir, A.N.; Kunkle, R.A.; Miller, J.M.; Hall, S.M. Abnormal Prion Protein in Ectopic Lymphoid Tissue in a Kidney of an Asymptomatic White-tailed Deer Experimentally Inoculated with the Agent of Chronic Wasting Disease. Veter. Pathol. 2006, 43, 367-369. [CrossRef]

173. Kaatz, M.; Fast, C.; Ziegler, U.; Balkema-Buschmann, A.; Hammerschmidt, B.; Keller, M.; Oelschlegel, A.; McIntyre, L.; Groschup, M.H. Spread of Classic BSE Prions from the Gut via the Peripheral Nervous System to the Brain. Am. J. Pathol. 2012, 181, 515-524. [CrossRef]

174. Seelig, D.M.; Mason, G.L.; Telling, G.C.; Hoover, E.A. Pathogenesis of Chronic Wasting Disease in Cervidized Transgenic Mice. Am. J. Pathol. 2010, 176, 2785-2797. [CrossRef]

175. Bartz, J.C.; de Joia, C.; Tucker, T.; Kincaid, A.E.; Bessen, R.A. Extraneural Prion Neuroinvasion without Lymphoreticular System Infection. J. Virol. 2005, 79, 11858-11863. [CrossRef]

176. Bartz, J.C.; Kincaid, A.E.; Bessen, R.A. Rapid Prion Neuroinvasion following Tongue Infection. J. Virol. 2003, $77,583-591$. [CrossRef]

177. Glatzel, M.; Aguzzi, A. PrPC expression in the peripheral nervous system is a determinant of prion neuroinvasion. J. Gen. Virol. 2000, 81, 2813-2821. [CrossRef] [PubMed]

178. Mammadova, N.; Cassmann, E.; Greenlee, J.J. Successful transmission of the chronic wasting disease (CWD) agent to white-tailed deer by intravenous blood transfusion. Res. Veter. Sci. 2020, 133, 304-306. [CrossRef]

179. Nalls, A.V.; McNulty, E.; Hoover, C.E.; Pulscher, L.A.; Hoover, E.A.; Mathiason, C.K. Infectious Prions in the Pregnancy Microenvironment of Chronic Wasting Disease-Infected Reeves' Muntjac Deer. J. Virol. 2017, 91, e00501-17. [CrossRef] [PubMed]

180. Henderson, D.M.; Manca, M.; Haley, N.J.; Denkers, N.D.; Nalls, A.V.; Mathiason, C.K.; Caughey, B.; Hoover, E.A. Rapid Antemortem Detection of CWD Prions in Deer Saliva. PLoS ONE 2013, 8, e74377. [CrossRef] [PubMed]

181. Plummer, I.H.; Wright, S.D.; Johnson, C.J.; Pedersen, J.A.; Samuel, M.D. Temporal patterns of chronic wasting disease prion excretion in three cervid species. J. Gen. Virol. 2017, 98, 1932-1942. [CrossRef]

182. Kramm, C.; Soto, P.; Nichols, T.A.; Morales, R. Chronic wasting disease (CWD) prion detection in blood from pre-symptomatic white-tailed deer harboring PRNP polymorphic variants. Sci. Rep. 2020, 10, 1-8. [CrossRef]

183. Bruce, M.; Chree, A.; Williams, E.; Fraser, H. Perivascular PrP amyloid in the brains of mice infected with chronic wasting disease. Brain Pathol. 2000, 10, 662-663.

184. Raymond, G.J.; Raymond, L.D.; Meade-White, K.D.; Hughson, A.G.; Favara, C.; Gardner, D.; Williams, E.S.; Miller, M.W.; Race, R.E.; Caughey, B. Transmission and Adaptation of Chronic Wasting Disease to Hamsters and Transgenic Mice: Evidence for Strains. J. Virol. 2007, 81, 4305-4314. [CrossRef]

185. Sigurdson, C.J.; Manco, G.; Schwarz, P.; Liberski, P.; Hoover, E.A.; Hornemann, S.; Polymenidou, M.; Miller, M.W.; Glatzel, M.; Aguzzi, A. Strain Fidelity of Chronic Wasting Disease upon Murine Adaptation. J. Virol. 2006, 80, 12303-12311. [CrossRef] [PubMed]

186. Heisey, D.M.; Mickelsen, N.A.; Schneider, J.R.; Johnson, C.J.; Johnson, C.J.; Langenberg, J.A. Chronic Wasting Disease (CWD) Susceptibility of Several North American Rodents That Are Sympatric with Cervid CWD Epidemics. J. Virol. 2010, 84, 210-215. [CrossRef] [PubMed]

187. Di Bari, M.A.; Nonno, R.; Castilla, J.; D’Agostino, C.; Pirisinu, L.; Riccardi, G.; Conte, M.; Richt, J.; Kunkle, R.; Langeveld, J.; et al. Chronic Wasting Disease in Bank Voles: Characterisation of the Shortest Incubation Time Model for Prion Diseases. PLoS Pathog. 2013, 9, e1003219. [CrossRef] [PubMed]

188. Perrott, M.R.; Sigurdson, C.J.; Mason, G.L.; Hoover, E.A. Evidence for distinct chronic wasting disease (CWD) strains in experimental CWD in ferrets. J. Gen. Virol. 2012, 93, 212-221. [CrossRef]

189. Sigurdson, C.; Mathiason, C.; Perrott, M.; Eliason, G.; Spraker, T.; Glatzel, M.; Manco, G.; Bartz, J.; Miller, M.; Hoover, E. Experimental Chronic Wasting Disease (CWD) in the Ferret. J. Comp. Pathol. 2008, 138, 189-196. [CrossRef]

190. Bartz, J.C.; Marsh, R.F.; McKenzie, D.I.; Aiken, J.M. The Host Range of Chronic Wasting Disease Is Altered on Passage in Ferrets. Virology 1998, 251, 297-301. [CrossRef]

191. Mathiason, C.K.; Nalls, A.V.; Seelig, D.M.; Kraft, S.L.; Carnes, K.; Anderson, K.R.; Hayes-Klug, J.; Hoover, E.A. Susceptibility of Domestic Cats to Chronic Wasting Disease. J. Virol. 2012, 87, 1947-1956. [CrossRef] 
192. Seelig, D.M.; Nalls, A.V.; Flasik, M.; Frank, V.; Eaton, S.; Mathiason, C.K.; Hoover, E.A. Lesion profiling and subcellular prion localization of cervid chronic wasting disease in domestic cats. Veter. Pathol. 2014, 52, 107-119. [CrossRef]

193. Waddell, L.; Greig, J.; Mascarenhas, M.; Otten, A.; Corrin, T.; Hierlihy, K. Current evidence on the transmissibility of chronic wasting disease prions to humans-A systematic review. Transbound. Emerg. Dis. 2017, 65, 37-49. [CrossRef]

194. Haley, N.J.; Hoover, E.A. Chronic Wasting Disease of Cervids: Current Knowledge and Future Perspectives. Annu. Rev. Anim. Biosci. 2015, 3, 305-325. [CrossRef]

195. Czub, S.; Schulz-Schaeffer, W.; Stahl-Hennig, C.; Beekes, M.; Schaetzl, H.; Motzkus, D. First evidence of intracranial and peroral transmission of chronic wasting disease (CWD) into cynomolgus macaques: A work in progress. In Proceedings of the (Abstract) from Prion 2017: Deciphering Neurodegenerative Disorders, Edinburgh, Scotland, 23-26 May 2017.

196. Moore, S.J.; Greenlee, M.H.W.; Kondru, N.; Manne, S.; Smith, J.D.; Kunkle, R.A.; Kanthasamy, A.; Greenlee, J.J. Experimental Transmission of the Chronic Wasting Disease Agent to Swine after Oral or Intracranial Inoculation. J. Virol. 2017, 91, e00926-17. [CrossRef] [PubMed]

197. Hamir, A.N.; Kunkle, R.A.; Cutlip, R.C.; Miller, J.M.; O’Rourke, K.I.; Williams, E.S.; Miller, M.W.; Stack, M.J.; Chaplin, M.J.; Richt, J.A. Experimental Transmission of Chronic Wasting Disease Agent from Mule Deer to Cattle by the Intracerebral Route. J. Veter. Diagn. Investig. 2005, 17, 276-281. [CrossRef]

198. Hamir, A.; Kunkle, R.; Miller, J.; Greenlee, J.; Richt, J. Experimental Second Passage of Chronic Wasting Disease (CWDmule deer) Agent to Cattle. J. Comp. Pathol. 2006, 134, 63-69. [CrossRef]

199. Hamir, A.N.; Miller, J.M.; Kunkle, R.A.; Hall, S.M.; Richt, J.A. Susceptibility of Cattle to First-passage Intracerebral Inoculation with Chronic Wasting Disease Agent from White-tailed Deer. Veter. Pathol. 2007, 44, 487-493. [CrossRef] [PubMed]

200. Hamir, A.N.; Kehrli, M.E.; Kunkle, R.A.; Greenlee, J.J.; Nicholson, E.M.; Richt, J.A. Experimental interspecies transmission studies of the transmissible spongiform encephalopathies to cattle: Comparison to bovine spongiform encephalopathy in cattle. J. VET Diagn. Invest. 2011, 23, 407-420. [CrossRef] [PubMed]

201. Williams, E.S.; O’Toole, D.; Miller, M.W.; Kreeger, T.J.; Jewell, J.E. Cattle (Bos Taurus) Resist Chronic Wasting Disease Following Oral Inoculation Challenge or Ten Years' Natural Exposure in Contaminated Eeniroments. J. Wildl. Dis. 2018, 54, 460-470. [CrossRef]

202. Tamgüney, G.; Giles, K.; Bouzamondo-Bernstein, E.; Bosque, P.J.; Miller, M.W.; Safar, J.; DeArmond, S.J.; Prusiner, S.B. Transmission of Elk and Deer Prions to Transgenic Mice. J. Virol. 2006, 80, 9104-9114. [CrossRef]

203. Sandberg, M.K.; Al-Doujaily, H.; Sigurdson, C.J.; Glatzel, M.; O’Malley, C.; Powell, C.; Asante, E.A.; Linehan, J.M.; Brandner, S.; Wadsworth, J.D.F.; et al. Chronic wasting disease prions are not transmissible to transgenic mice overexpressing human prion protein. J. Gen. Virol. 2010, 91, 2651-2657. [CrossRef]

204. Wadsworth, J.D.F.; Asante, E.A.; Desbruslais, M.; Linehan, J.M.; Joiner, S.; Gowland, I.; Welch, J.; Stone, L.; Lloyd, S.E.; Hill, A.F.; et al. Human Prion Protein with Valine 129 Prevents Expression of Variant CJD Phenotype. Science 2004, 306, 1793-1796. [CrossRef]

205. Dickinson, A.G.; Meikle, V.M.H. Host-genotype and agent effects in scrapie incubation: Change in allelic interaction with different strains of agent. Mol. Genet. Genom. 1971, 112, 73-79. [CrossRef]

206. Benestad, S.L.; Arsac, J.-N.; Goldmann, W.; Nöremark, M. Atypical/Nor98 scrapie: Properties of the agent, genetics, and epidemiology. Veter. Res. 2008, 39, 19. [CrossRef]

207. Anderson, C.A.; Bosque, P.; Filley, C.M.; Arciniegas, D.B.; Kleinschmidt-Demasters, B.K.; Pape, W.J.; Tyler, K.L. Colorado Surveillance Program for Chronic Wasting Disease Transmission to Humans: Lessons From 2 Highly Suspicious but Negative Cases. Arch Neurol. 2007, 64, 439. [CrossRef]

208. Mawhinney, S.; Pape, W.J.; Forster, J.E.; Anderson, C.A.; Bosque, P.; Miller, M.W. Human Prion Disease and Relative Risk Associated with Chronic Wasting Disease. Emerg. Infect. Dis. 2006, 12, 1527-1535. [CrossRef]

209. Belay, E.D.; Gambetti, P.; Schonberger, L.B.; Parchi, P.; Lyon, D.R.; Capellari, S.; McQuiston, J.H.; Bradley, K.; Dowdle, G.; Crutcher, J.M.; et al. Creutzfeldt-Jakob Disease in Unusually Young Patients Who Consumed Venison. Arch. Neurol. 2001, 58, 1673-1678. [CrossRef]

210. Olszowy, K.; Lavelle, J.; Rachfal, K.; Hempstead, S.; Drouin, K.; Darcy, J.; Reiber, C.; Garruto, R. Six-year follow-up of a pointsource exposure to CWD contaminated venison in an Upstate New York Community: Risk behaviours and health outcomes 2005-2011. Public Health 2014, 128, 860-868. [CrossRef]

211. Barria, M.A.; Telling, G.C.; Gambetti, P.; Mastrianni, J.A.; Soto, C. Generation of a New Form of Human PrPSc in Vitro by Interspecies Transmission from Cervid Prions. J. Biol. Chem. 2011, 286, 7490-7495. [CrossRef]

212. Kong, Q.; Huang, S.; Zou, W.; Vanegas, D.; Wang, M.; Wu, D.; Yuan, J.; Zheng, M.; Bai, H.; Deng, H.; et al. Chronic Wasting Disease of Elk: Transmissibility to Humans Examined by Transgenic Mouse Models. J. Neurosci. 2005, 25, 7944-7949. [CrossRef] [PubMed]

213. Race, B.; Williams, K.; Chesebro, B. Transmission studies of chronic wasting disease to transgenic mice overexpressing human prion protein using the RT-QuIC assay. Vet. Res. 2019, 50, 6. [CrossRef] [PubMed]

214. Race, B.; Meade-White, K.D.; Miller, M.W.; Barbian, K.D.; Rubenstein, R.; LaFauci, G.; Cervenáková, L.; Favara, C.; Gardner, D.; Long, D.; et al. Susceptibilities of Nonhuman Primates to Chronic Wasting Disease. Emerg. Infect. Dis. 2009, 15, $1366-1376$. [CrossRef] 
215. Race, B.; Williams, K.; Orru, C.D.; Hughson, A.G.; Lubke, L.; Chesebro, B. Lack of Transmission of Chronic Wasting Disease to Cynomolgus Macaques. J. Virol. 2018, 92. [CrossRef] [PubMed]

216. Race, B.; Meade-White, K.D.; Phillips, K.; Striebel, J.; Race, R.; Chesebro, B. Chronic Wasting Disease Agents in Nonhuman Primates. Emerg. Infect. Dis. 2014, 20, 833-837. [CrossRef] [PubMed]

217. Osterholm, M.T.; Anderson, C.J.; Zabel, M.D.; Scheftel, J.M.; Moore, K.A.; Appleby, B.S. Chronic Wasting Disease in Cervids: Implications for Prion Transmission to Humans and Other Animal Species. mBio 2019, 10. [CrossRef] [PubMed]

218. Comoy, E.E.; Mikol, J.; Luccantoni-Freire, S.; Correia, E.; Lescoutra-Etchegaray, N.; Durand, V.; Dehen, C.; Andreoletti, O.; Casalone, C.; Richt, J.A.; et al. Transmission of scrapie prions to primate after an extended silent incubation period. Sci. Rep. 2015, 5. [CrossRef] [PubMed] 